\title{
"THE GOOD, THE BAD, THE WEIRD": STONE AGE AND EARLY METAL PERIOD RADIOCARBON DATES AND CHRONOLOGY FROM THE KARELIAN ISTHMUS, NORTH-WEST RUSSIA
}

\author{
OULA SEITSONEN ${ }^{1}$, KERKKO NORDQVIST ${ }^{2}$, DMITRIJ V. GERASIMOV ${ }^{3}$ and SERGEI N. LISITSYN ${ }^{4}$ \\ ${ }^{1}$ Arkteekki ltd. / The Department of Geosciences and Geography, P.O. Box 64, FI-00014 University of Helsinki, Finland \\ ${ }^{2}$ The Department of Philosophy, History, Culture and Art Studies, P.O. Box 59, FI-00014 University of Helsinki, Finland \\ ${ }^{3}$ Peter the Great's Museum of Anthropology and Ethnography (Kunstkamera), Russian Academy of Sciences, \\ Universitetskaja Nab. D. 3, RU-199034, St. Petersburg, Russia \\ ${ }^{4}$ Institute for the History of Material Culture, Russian Academy of Sciences, Dvorcovaja Nab. 18, RU-191186. St. Petersburg, Russia
}

Received 20 December 2010

Accepted 21 September 2011

\begin{abstract}
In this paper all the Stone Age and Early Metal Period (ca. 8600 cal BC - 300 AD) radiocarbon dates from the Karelian Isthmus, Russia, are compiled and their archaeological usability assessed using a set of evaluation principles. The quality of radiometric dates from such a large area has rarely been methodologically examined in Finnish or North-West Russian archaeology, and is applied here for the first time on the present material. Special attention is given to the discussion on the deficiencies and limitations of the current data. Based on the 81 dates evaluated as useful, a tentative radiocarbon chronology is presented for the study area. This is generally in sequence with the chronologies of the nearby areas, but suggests some differences especially towards the end of Stone Age, as well as the presence of biases caused by taphonomic and research-related factors.
\end{abstract}

Keywords: Archaeology, ${ }^{14} \mathrm{C}$ dates, radiocarbon chronology, Holocene, Karelian Isthmus, Finland, Russia.

\section{INTRODUCTION}

The Karelian Isthmus, located in North-West Russia between Lake Ladoga and Gulf of Finland, was the stage of extensive Stone Age studies in the early $20^{\text {th }}$ century (e.g. Pälsi, 1920a; also Uino, 2003; Nordqvist et al., 2009). A vast amount of archaeological material was unearthed then, but as the studies pre-dated the invention of radiocarbon method, dating relied mostly on typological schemes and later also on shoreline displacement chronology. The period when radiocarbon dating started to become a standard tool for constructing archaeological

Corresponding author: O. Seitsonen

e-mail: oula.seitsonen@helsinki.fi chronologies coincides in the study area with the postWorld War II standstill of research, and most of the area remained thinly studied until the collapse of Soviet Union (see e.g. Uino, 2003; Nordqvist et al., 2009; Fig. 1).

Stone Age and Early Metal Period research in the northern part of Karelian Isthmus has intensified again only during the last decade as a result of several FinnoRussian joint research projects (e.g. Lavento (ed.), 2008; Nordqvist et al., 2009) ${ }^{1}$. Also the parts of study area

\footnotetext{
${ }^{1}$ The research has mostly taken place within the projects of the Department of Archaeology, University of Helsinki, Finland and two organs of the Russian Academy of Sciences in St. Petersburg, namely the Institute for the History of Material Culture and Peter the Great's Museum of Anthropology and Ethnography (Kunstkamera) (e.g. Lavento (ed.), 2008; Sapelko et al., 2008; Nordqvist et al., 2009). Some studies have
} 


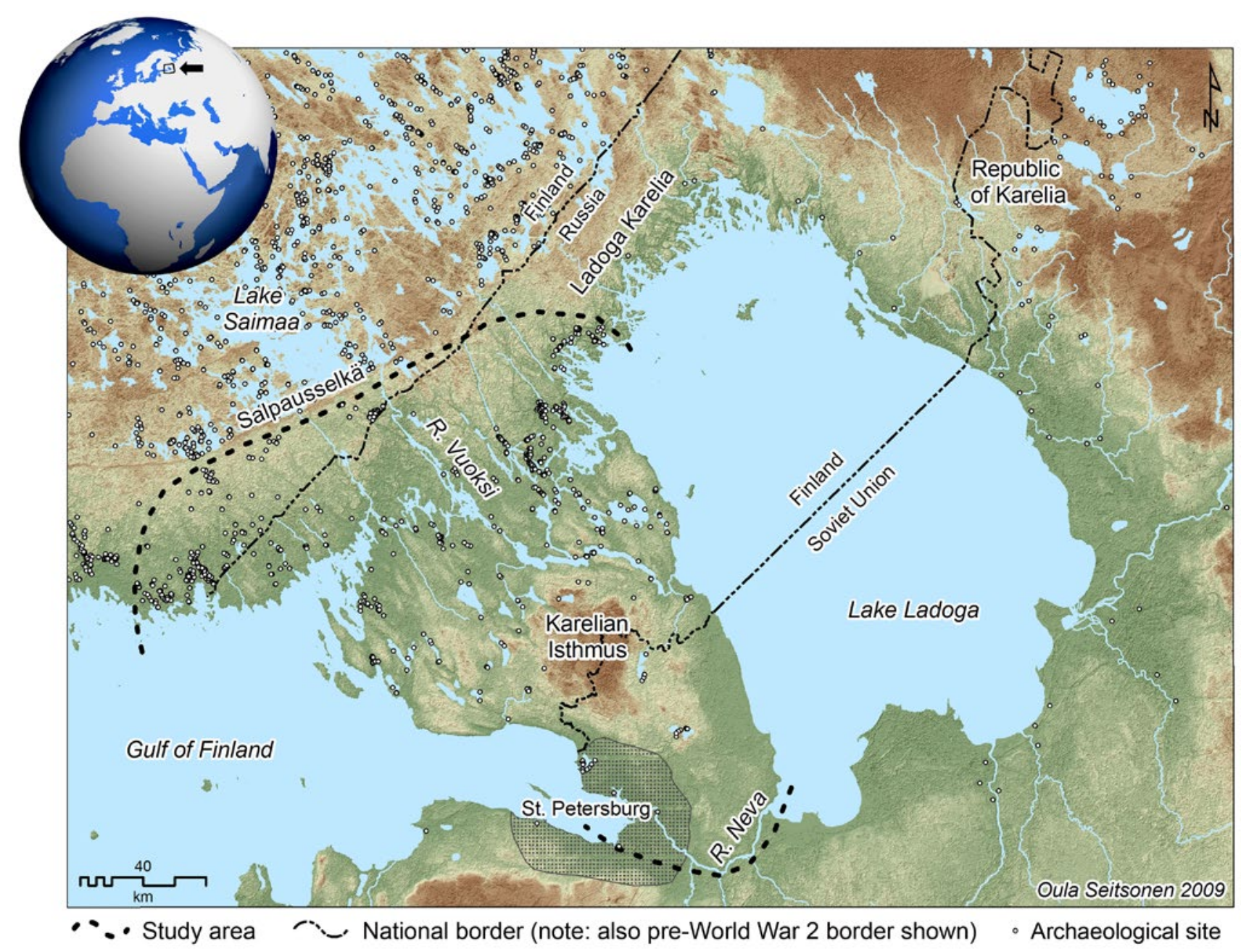

Fig. 1. The study area (bordered with dotted line) comprises the Karelian Isthmus and south-western parts of Ladoga Karelia, Russia, and the southeastern corner of Finland up to the watershed formed by Salpausselkä end moraine - the whole area is referred as Karelian Isthmus for brevity's sake. Also the Stone Age and Early Metal Period sites known up to 2010 are shown (white dots; based on the KarAS database) (Map: O. Seitsonen).

belonging to Finland have recently faced increased research activity (e.g. Jussila et al., 2007; Mökkönen and Seitsonen, 2007; Mökkönen, 2008). Conversely, the southern part of the study area has so far remained meagerly studied, with a few exceptions (see Vereščagina, 2003; Sorokin et al., 2009).

The first attempt to date Stone Age contexts in the Karelian Isthmus with radiocarbon method was carried out by S.I. Rudenko in the 1960 s, but the dates proved to be problematic (Rudenko, 1970). Both archaeological studies and the number of radiometric dates remained low till the end of 1990s: recent increase in fieldwork has also meant a rapid and substantial upswing in the number of

also been made as collaboration of Lahti City Museum, Finland and the above-mentioned Russian institutions (e.g. Takala and Sirviö, 2003; Takala, 2004). The authors have participated in these projects since their very beginning, and currently direct the ongoing field research in the area of Karelian Isthmus (e.g. Gerasimov et al., 2007; 2008; Seitsonen et al., 2009). archaeological ${ }^{14} \mathrm{C}$ dates. This enables for the first time the construction of a preliminary regional radiocarbon chronology for the study area. The pace is illustrated if we compare the previous compilations of Stone Age and Early Metal Period radiocarbon dates from the Karelian Isthmus (Uino, 1997; Saarnisto (ed.), 2003; Timofeev et al., 2004a; Timofeev et al., 2004b ${ }^{2}$ ) with the current situation: earlier compilations included altogether 39 dates from 16 Stone Age and Early Metal Period sites, while in this paper we present 94 conventional and AMS dates from 40 sites, over $10 \%$ of them previously unpublished.

In the first half of this paper all the radiometric dates from Stone Age and Early Metal Period contexts availa-

\footnotetext{
${ }^{2}$ In their article Timofeev et al. (2004a) published 30 dates from 13 locations. For some reason not all the dates available at that time were included, and due to the delimiting of study area also nine dates presented in Saarnisto ((ed.) 2003: 512) were left out - the latter account includes 19 Stone Age and Early Metal Period dates from 11 sites.
} 
ble from the study area by the end of 2009 are compiled and their usability for building an archaeological radiocarbon chronology evaluated. The evaluation of radiometric dates has become more common over the past decade (e.g. Kuzmin and Tankerslay, 1996; Pettitt et al., 2003; Graf, 2009), but has not been consistently practiced in the study area earlier - also from a more wide-ranging viewpoint the assessment of radiometric dates in Holocene contexts has largely depended on each researcher's personal interests and motivation (e.g. Gkiasta et al., 2003: 48).

In the second half of the paper the dated samples and their contexts are presented according to the major chronological periods, and a tentative ${ }^{14} \mathrm{C}$ chronology presented for the Karelian Isthmus. We also examine the possibilities proposed chronology and present dwelling site data possess for making interpretations of the spread and scale of prehistoric settlement and population dynamics in the Karelian Isthmus over time (see e.g. Kuzmin and Orlova, 2000; Dolukhanov et al., 2005; Zaitseva and Dergachev, 2009; Tallavaara et al., 2010), and the constraints set by the current, on no account optimal, research situation, as well as other factors, such as the environmental history (see Surovell and Brantingham, 2007; Surovell et al., 2009).

\section{EVALUATION OF THE RADIOCARBON DATES}

Numerous researchers have lately reminded that "Dates are not just data" (e.g. Kuzmin and Keates, 2005). Methodically sound and reproducible evaluation principles are needed when working with archaeological radiocarbon dates, and accordingly assessment criteria has been suggested on occasions since the 1970s (e.g. Waterbolk, 1971; Spriggs, 1989; Kuzmin and Tankerslay, 1996).

In this paper, all ${ }^{14} \mathrm{C}$ dates available from the study area by the end of 2009 are evaluated with a ranking system based on the criteria presented by Pettitt et al. (2003) and Graf (2009), and adapted to fit our KarAS database $^{3}$. We developed our assessment criteria on the basis of an interpretative viewpoint related to the archaeological context of each sample, with focus on three major themes: the association of the sample and the dated hominin-influenced event; the compatibility of the date with other data from the site; and the quality of the sample and date itself (Table 1). Since all dates have been processed by acknowledged radiocarbon laboratories, we did not feel a need for assessing the chronometric issues connected to the formal analyses (Pettitt et al., 2003: criteria 1-5).

\footnotetext{
${ }^{3}$ Seitsonen has assembled from numerous sources, including our primary fieldwork data, a constantly growing KarAS (Karelian Archaeological Sites) database, which includes relevant data of all the known prehistoric sites. Researchers interested in this information can contact him. KarAS database is also going to be published online in the future.
}

All the Stone Age and Early Metal Period radiocarbon dates from the study area are compiled in Table $2^{4}$. A case-by-case approach was chosen to evaluate the quality of the dates: each date was scored from 0 to 4 for all the criteria (Table 1), and the overall score summed (Table 2). Finally the dates were divided into three categories according to the score: 20-28 "Good", 10-19 "Weird" and 0-9 "Bad" (Fig. 2), equivalent to the characters in the South Korean Western movie "The Good, the Bad, the Weird" (Kim Ji-woon, CJ Entertainment; cf. Graf, 2009).

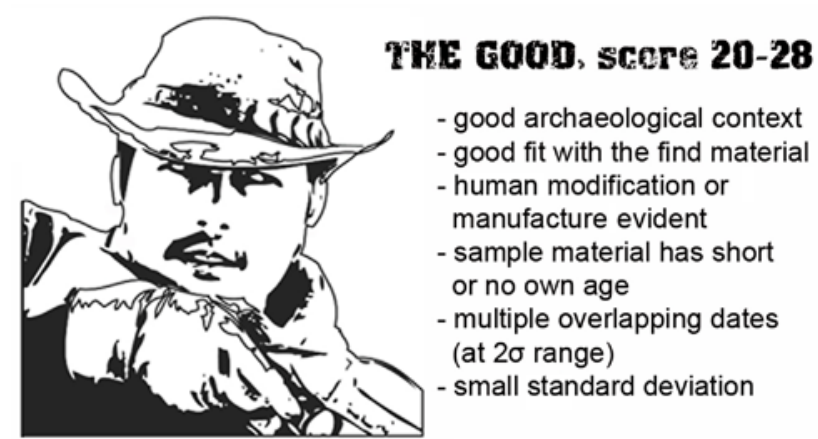

TKE BAD, scere 0-9

$$
\begin{aligned}
& \text { - doubtful archaeological } \\
& \text { context } \\
& \text { - does not fit with the find } \\
& \text { material } \\
& \text { - sample material might } \\
& \text { have high own age } \\
& \text { - no overlapping } \\
& \text { dates (at } 2 \sigma \text { range) } \\
& \text { - large standard deviation }
\end{aligned}
$$
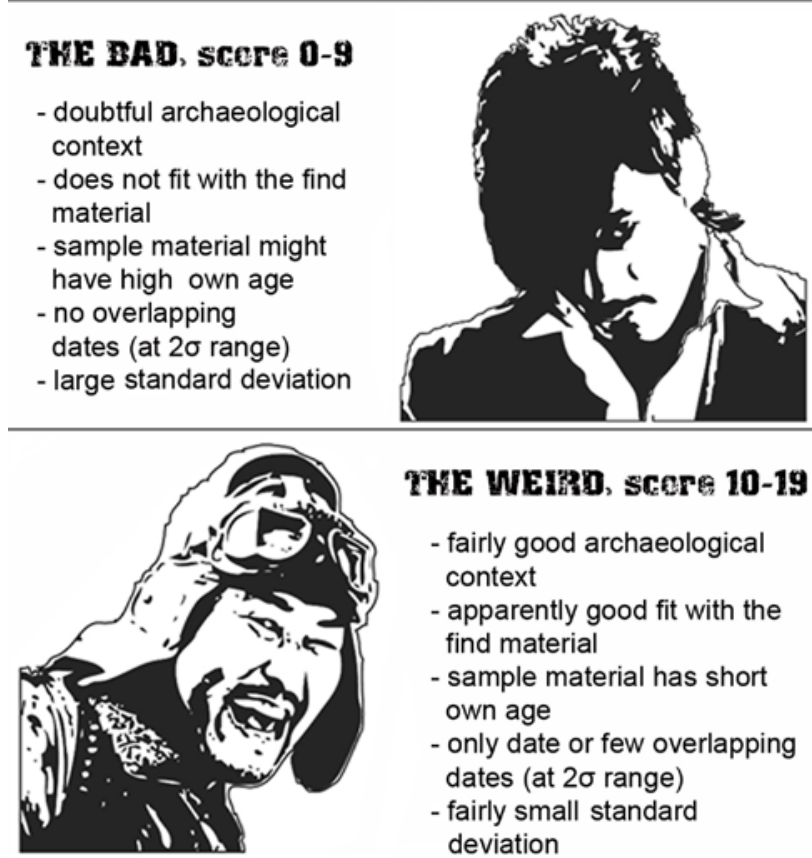

TKE WEIRD, scere 10-19

- fairly good archaeological context

- apparently good fit with the find material

- sample material has short own age

- only date or few overlapping

dates (at $2 \sigma$ range)

- fairly small standard

deviation

Fig. 2. "The Good, the Bad, the Weird": an evaluation framework for the archaeological radiocarbon dates from the Karelian Isthmus (IIlustration: O. Seitsonen).

\footnotetext{
${ }^{4}$ In this paper the Finnish names of sites and administrative areas located in the northern Karelian Isthmus, part of Finland prior to World War II (Fig. 1), are used, because the main corpus of the extensive material collected here is catalogued under and discussed according to these names in the archival material and archaeological literature - the Russian names can be found in the referred literature (see also e.g. Gerasimov et al., 2003; Nordqvist et al., 2008).
} 
The dates entitled "Good" $(\mathrm{N}=42)$ originate from a number of meticulously sampled, recently excavated sites, with multiple dates from each context. The "Weird" dates $(\mathrm{N}=39)$ consist mostly of solitary dates; Although in many cases these show a relatively good fit with the excavated materials on a face value, it should be remembered that "one date is no date" (e.g. Pettitt et al., 2003), as they cannot be cross-checked. The dates which re- ceived the evaluation "Bad" $(\mathrm{N}=11)$ for their archaeological usability, are omitted from further examinations. Most of these evidently date some other incidents than human activities, e.g. periodical forest fires (Jussila et al. 2007). There are also two "Good" dates which date later events, from Muolaa Silino 1 and Kaukola Rupunkangas 1 sites; these too are excluded from the following assessment.

Table 1. Criteria used in the evaluation of radiocarbon dates (1-4 based on Pettitt et al. (2003), 5-7 based on Graf (2009), and modified to fit the data from the study area).

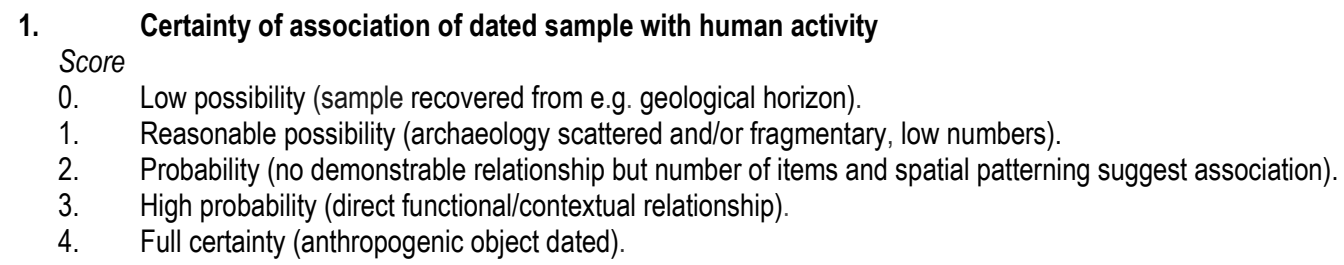

0. Sample material is unknown.

1. Sample has no traces of human modification, or if charcoal, "old wood" effect cannot be ruled out.

2. Sample has high association with diagnostic archaeology, through incorporation in same horizon/level, but is in itself undiagnostic.

3. Sample has very high association, through incorporation into cultural feature, e.g. hearth or pit, albeit undiagnostic itself.

4. Sample culturally diagnostic, or has a high probability of association, or has traces of human modification.

3. Quantity and nature of dates for archaeological horizon

Score

0 . The date is one of several for a given horizon that differ statistically at $2 \sigma$ range.

1. The date is the sole measurement for a given horizon.

2. The date is one of 2 dates for a given horizon which are statistically the same age at $2 \sigma$ range.

3. The date is one of 3 dates for a given horizon which are statistically the same age at $2 \sigma$ range.

4. The date is one of 4 or more dates for a given horizon which are statistically the same age at $2 \sigma$ range.

4. Stratigraphic issues

Score

0. Sample is a small fragment which may be stratigraphically mobile, with no spatial indication of its stratigraphic integrity.

1. Sample is $<5 \mathrm{~cm}$ in maximum dimension with no clear indication of its stratigraphic integrity.

2. Sample is $<5 \mathrm{~cm}$ in maximum dimension with a high probability of stratigraphic integrity.

3. Sample is $>5 \mathrm{~cm}$ in maximum dimension with a high probability of stratigraphic integrity.

4. Sample is $>5 \mathrm{~cm}$ in maximum dimensions and clearly stratified within an identifiable cultural feature.

5.

Score

0 . Dispersed material whose stratigraphic context is not clear.

1. Charcoal from a clear archaeological horizon, "old wood" effect cannot be ruled out.

2. Burnt bone from a clear archaeological horizon.

3. Charcoal or burnt bone from a hearth or other cultural feature, or human modified material with which "old wood" effect cannot be ruled out.

4. Charred crust, resin, cut-marked burnt bone or other human modified material, "old wood" effect ruled out.

6. Standard deviation

Score

0. $> \pm 100$

1. $\pm 71-100$

2. $\quad \pm 51-70$

3. $\pm 40-50$

4. $< \pm 40$

7. Fittingness with the archaeological find material and stratigraphy

Score

0 . No obvious correlation between the date and find context or context unknown

1. The date does not fit the find context but overlaps at $2 \sigma$ range with 1 or more other dates in a given horizon.

2. The date fits the find context but is the sole measurement or does not overlap with other dates at $2 \sigma$ range.

3. The date fits the find context and overlaps at $2 \sigma$ range with 1 other date.

4. The date fits the find context and overlaps at $2 \sigma$ range with atleast 2 other dates. 
Table 2. Archaeological radiocarbon dates from the study area; calibrated with OxCal 4.0, (Bronk Ramsey, 2001), using the IntCal09 calibration curve for the Northern Hemisphere (Reimer et al., 2009).

\begin{tabular}{|c|c|c|c|c|c|c|c|c|c|c|c|c|c|c|c|}
\hline \multirow{2}{*}{\begin{tabular}{|l|} 
Si- \\
te \\
nr. \\
\end{tabular}} & \multirow{2}{*}{ Site } & \multirow{2}{*}{$\begin{array}{l}\text { Da- } \\
\text { te } \\
\text { nr. }\end{array}$} & \multirow{2}{*}{ Context } & \multirow[b]{2}{*}{ Material } & \multirow[b]{2}{*}{ Lab. nr. } & \multirow[b]{2}{*}{ BP } & \multirow[b]{2}{*}{ SD } & \multicolumn{3}{|c|}{ Cal $(68.2 \%)$} & \multicolumn{3}{|c|}{ Cal $(95.4 \%)$} & \multirow{2}{*}{$\begin{array}{l}\mathrm{Ra}- \\
\text { ting }\end{array}$} & \multirow{2}{*}{$\begin{array}{l}\text { Refe- } \\
\text { rences }\end{array}$} \\
\hline & & & & & & & & $\max$ & $\min$ & & $\max$ & $\min$ & & & \\
\hline 1 & \begin{tabular}{|l|} 
Antrea \\
(Vuoksenranta) \\
Korpilahti
\end{tabular} & $\begin{array}{l}1 \\
2 \\
3\end{array}$ & $\begin{array}{l}\text { EM, net float, NM } 6688^{\circ} \\
\text { EM, net float, NM } 6688 \\
\text { EM, net cord, NM } 6688\end{array}$ & $\begin{array}{l}\text { pine bark } \\
\text { pine bark } \\
\text { willow cord }\end{array}$ & \begin{tabular}{|l|} 
Hel-1303 \\
Hel-269 \\
Hela-404 \\
\end{tabular} & $\begin{array}{l}9310 \\
9230 \\
9140 \\
\end{array}$ & $\begin{array}{l}140 \\
210 \\
135 \\
\end{array}$ & $\begin{array}{l}8730 \\
8790 \\
8560\end{array}$ & $\begin{array}{l}8340 \\
8230 \\
8240 \\
\end{array}$ & \begin{tabular}{|l|}
$\mathrm{BC}$ \\
$\mathrm{BC}$ \\
$\mathrm{BC}$ \\
\end{tabular} & $\begin{array}{l}9130 \\
9210 \\
8740 \\
\end{array}$ & $\begin{array}{l}8270 \\
7940 \\
7960 \\
\end{array}$ & $\begin{array}{l}\mathrm{BC} \\
\mathrm{BC} \\
\mathrm{BC}\end{array}$ & \begin{tabular}{|l|}
22 \\
22 \\
23 \\
\end{tabular} & $\begin{array}{l}1,2,3,4 \\
1,2,3,4 \\
4,5,6,7 \\
\end{array}$ \\
\hline 2 & $\begin{array}{l}\text { Antrea Suuri } \\
\text { Kelpojärvi }\end{array}$ & 4 & EM, cultural layer & burnt bone & Hela-931 & 9275 & 120 & 8640 & 8320 & $B C$ & 9110 & 8250 & $B C$ & 13 & 8,9 \\
\hline \multirow[b]{2}{*}{3} & \multirow{2}{*}{$\begin{array}{l}\text { Heinjoki } \\
\text { Latukangas } 1 \\
\text { (Veschevo 1) }\end{array}$} & \multirow{2}{*}{$\begin{array}{l}5 \\
6 \\
7\end{array}$} & \multirow{2}{*}{$\begin{array}{l}\text { EN, CW1, charcoal } \\
\text { concentration } \\
\text { EMP, cultural layer } \\
\text { MIA?, cultural layer } \\
\end{array}$} & charcoal & Le-6511 & 5770 & 130 & 4780 & 4460 & $B C$ & 4940 & 4350 & $B C$ & 17 & 10,11 \\
\hline & & & & $\begin{array}{l}\text { charcoal } \\
\text { charcoal }\end{array}$ & \begin{tabular}{|l} 
Le-6559 \\
Le-6509 \\
\end{tabular} & $\begin{array}{l}2400 \\
1470 \\
\end{array}$ & $\begin{array}{c}50 \\
140 \\
\end{array}$ & $\begin{array}{l}720 \\
414 \\
\end{array}$ & $\begin{array}{l}390 \\
680 \\
\end{array}$ & $\begin{array}{l}B C \\
A D \\
\end{array}$ & $\begin{array}{l}760 \\
250 \\
\end{array}$ & $\begin{array}{l}390 \\
870\end{array}$ & $\begin{array}{l}B C \\
A D \\
\end{array}$ & $\begin{array}{c}18 \\
7 \\
\end{array}$ & $\begin{array}{l}10,11 \\
10,11 \\
\end{array}$ \\
\hline 4 & \begin{tabular}{|l|} 
Heinjoki \\
Tarhojenranta
\end{tabular} & 8 & EN, charcoal patch & charcoal & $\mathrm{N} / \mathrm{A}$ & 5815 & 50 & 4730 & 4590 & $B C$ & 4790 & 4540 & $\mathrm{BC}$ & 14 & 12 \\
\hline 5 & \begin{tabular}{|l|} 
Heinjoki \\
Valklampi 1 \\
\end{tabular} & 9 & EM, cultural layer & burnt bone & Hela-743 & 8765 & 65 & 7960 & 7680 & $B C$ & 8190 & 7600 & $\mathrm{BC}$ & 14 & 8,9 \\
\hline 6 & $\begin{array}{l}\text { Heinjoki } \\
\text { Valklampi } 2 \\
\end{array}$ & 10 & EM, cultural layer & burnt bone & Hela-744 & 8720 & 70 & 7830 & 7600 & $B C$ & 8170 & 7580 & $\mathrm{BC}$ & 13 & 8,9 \\
\hline 7 & Hepojärvi & $\begin{array}{l}11 \\
12 \\
13 \\
14 \\
\end{array}$ & $\begin{array}{l}\mathrm{LM} / \mathrm{EN}, \text { hearth } \\
\mathrm{LM} / \mathrm{EN} \text {, hearth } \\
\mathrm{LN} \text {, org, hearth } \\
\mathrm{LN} \text {, org, pit feature }\end{array}$ & $\begin{array}{l}\text { charcoal } \\
\text { charcoal } \\
\text { charcoal } \\
\text { charcoal }\end{array}$ & \begin{tabular}{|l} 
Le-1412 \\
Le-1411 \\
Le-1410 \\
Le-1408 \\
\end{tabular} & $\begin{array}{l}6480 \\
6380 \\
4100 \\
4020 \\
\end{array}$ & $\begin{array}{l}60 \\
60 \\
60 \\
70 \\
\end{array}$ & $\begin{array}{l}5490 \\
5470 \\
2860 \\
2840\end{array}$ & $\begin{array}{l}5370 \\
5310 \\
2570 \\
2460 \\
\end{array}$ & \begin{tabular}{l|}
$\mathrm{BC}$ \\
$\mathrm{BC}$ \\
$\mathrm{BC}$ \\
$\mathrm{BC}$ \\
\end{tabular} & $\begin{array}{l}5550 \\
5480 \\
2880 \\
2870 \\
\end{array}$ & $\begin{array}{l}5320 \\
5220 \\
2490 \\
2340 \\
\end{array}$ & $\begin{array}{l}\mathrm{BC} \\
\mathrm{BC} \\
\mathrm{BC} \\
\mathrm{BC}\end{array}$ & \begin{tabular}{|l|}
20 \\
20 \\
20 \\
19 \\
\end{tabular} & \begin{tabular}{|l|}
$11,14,15$ \\
$11,14,15$ \\
$11,14,15$ \\
$11,14,15$ \\
\end{tabular} \\
\hline 8 & $\begin{array}{l}\text { Johannes } \\
\text { Loikas }\end{array}$ & 15 & LN, cord?, hearth & charcoal & Hela-663 & 3860 & 45 & 2460 & 2230 & $B C$ & 2470 & 2200 & $\mathrm{BC}$ & 16 & 16,17 \\
\hline 9 & \begin{tabular}{|l|} 
Johannes \\
Tokarevo 1:1
\end{tabular} & 16 & MN, CW2, potsherd & charred crust & Ki-10298 & 4790 & 210 & 3930 & 3340 & $B C$ & 4040 & 2940 & $\mathrm{BC}$ & 19 & $16,17,18$ \\
\hline 10 & $\begin{array}{l}\text { Johannes } \\
\text { Väntsi }\end{array}$ & 17 & $\begin{array}{l}\text { MN, Kierikki, potsherd, } \\
\text { NM 9406:188 }\end{array}$ & charred crust & Hela-465 & 4870 & 85 & 3770 & 3530 & $B C$ & 3940 & 3370 & $\mathrm{BC}$ & 20 & $11,16,17$ \\
\hline \multirow{2}{*}{11} & \multirow{2}{*}{$\begin{array}{l}\text { Joutseno } \\
\text { Saarenoja } 2\end{array}$} & \multirow[t]{2}{*}{18} & \multirow{2}{*}{$\begin{array}{l}\text { EM, cultural layer } \\
\text { EM, cultural layer }\end{array}$} & \multirow{2}{*}{$\begin{array}{l}\text { burnt bone } \\
\text { charred plant } \\
\text { remains }\end{array}$} & Hela-728 & 9310 & 75 & 8710 & 8450 & $B C$ & 8750 & 8320 & $\mathrm{BC}$ & 15 & 34 \\
\hline & & & & & Hela-470 & 7720 & 115 & 6680 & 6440 & $B C$ & 7030 & 6370 & $\mathrm{BC}$ & 3 & 35 \\
\hline 12 & \begin{tabular}{|l|} 
Joutseno \\
Hiekkasilta- \\
Hiekkakuoppa \\
\end{tabular} & 20 & EM?, cultural layer & $\begin{array}{l}\text { charred pine } \\
\text { cone frag- } \\
\text { ments }\end{array}$ & Hela-472 & 6430 & 75 & 5480 & 5340 & $B C$ & 5540 & 5220 & $\mathrm{BC}$ & $53^{3}$ & 35 \\
\hline 13 & \begin{tabular}{|l|} 
Joutseno \\
Saarenoja- \\
Muilamäki \\
\end{tabular} & 21 & EM?, cultural layer & $\begin{array}{l}\text { charred pine } \\
\text { cone frag- } \\
\text { ments }\end{array}$ & Hela-471 & 4050 & 70 & 2840 & 2470 & $B C$ & 2880 & 2450 & $B C$ & $53^{3}$ & 35 \\
\hline 14 & $\begin{array}{l}\text { Kanneljärvi } \\
\text { Kanneljärvi } 2\end{array}$ & \multicolumn{2}{|c|}{\begin{tabular}{l|l}
22 & $\mathrm{LN}$, charcoal concentra- \\
tion \\
23
\end{tabular}} & $\begin{array}{l}\text { charcoal } \\
\text { charcoal }\end{array}$ & $\begin{array}{l}\text { Le-2549 } \\
\text { Le-2550 }\end{array}$ & $\begin{array}{l}3890 \\
3500\end{array}$ & $\begin{array}{l}40 \\
40\end{array}$ & $\begin{array}{l}2470 \\
1890\end{array}$ & $\begin{array}{l}2340 \\
1770\end{array}$ & $\begin{array}{l}B C \\
B C\end{array}$ & $\begin{array}{l}2480 \\
1940\end{array}$ & $\begin{array}{l}2210 \\
1690\end{array}$ & $\begin{array}{l}B C \\
B C\end{array}$ & $\left.17\right|^{1}$ & 10,15 \\
\hline 15 & \begin{tabular}{|l|} 
Kaukola Juho \\
Paavilaisen \\
Rantapelto \\
(Kankaanmäki) \\
\end{tabular} & 24 & $\begin{array}{l}\text { EMP, potsherd, NM } \\
\text { 7117:24 }\end{array}$ & charred crust & Hela-467 & 3085 & 70 & 1430 & 1260 & $B C$ & 1500 & 1130 & $\mathrm{BC}$ & $20{ }_{3}^{1}$ & $\begin{array}{l}11,17,19, \\
31\end{array}$ \\
\hline 16 & \begin{tabular}{|l|}
$\begin{array}{l}\text { Kaukola } \\
\text { Piiskunsalmi } \\
\text { Lavamäki }\end{array}$ \\
\end{tabular} & 25 & $\begin{array}{l}\text { LN, cord, potsherd NM } \\
6385: 21\end{array}$ & charred crust & Hela-468 & 4130 & 60 & 2870 & 2620 & $B C$ & 2890 & 2500 & $\mathrm{BC}$ & $\left.21\right|_{3} ^{1}$ & $\begin{array}{l}11,17,19, \\
33\end{array}$ \\
\hline 17 & \begin{tabular}{|l|} 
Kaukola \\
Riukjärvi \\
(Kyöstälänhar- \\
ju)
\end{tabular} & 26 & $\begin{array}{l}\text { MN, CW3, potsherd NM } \\
5699: 9\end{array}$ & birch bark tar & Hela-359 & 4780 & 70 & 3650 & 3380 & $B C$ & 3700 & 3370 & $\mathrm{BC}$ & $\left.20\right|_{3} ^{1}$ & $\begin{array}{l}11,17,19, \\
32\end{array}$ \\
\hline 18 & $\begin{array}{l}\text { Kaukola } \\
\text { Rupunkangas } \\
1 \mathrm{~A}\end{array}$ & $\begin{array}{l}27 \\
28 \\
29 \\
30 \\
31\end{array}$ & $\begin{array}{l}\text { EM, inside a house-pit } \\
\text { EM, inside a house-pit } \\
\text { LM, inside a house-pit } \\
\text { LM, inside a house-pit } \\
\text { historical, tar-burning pit }\end{array}$ & $\begin{array}{l}\text { charcoal } \\
\text { charcoal } \\
\text { charcoal } \\
\text { charcoal } \\
\text { charcoal }\end{array}$ & \begin{tabular}{|l|} 
Hela-1182 \\
Hela-1197 \\
Hela-1196 \\
Hela-1195 \\
Hela-1183 \\
\end{tabular} & $\begin{array}{c}8770 \\
8130 \\
7550 \\
6595 \\
205 \\
\end{array}$ & $\begin{array}{l}85 \\
65 \\
75 \\
55 \\
40 \\
\end{array}$ & $\begin{array}{l}8170 \\
7290 \\
6480 \\
5610 \\
1650 \\
\end{array}$ & $\begin{array}{l}7650 \\
7040 \\
6260 \\
5480 \\
1960 \\
\end{array}$ & \begin{tabular}{|l|}
$B C$ \\
$B C$ \\
$B C$ \\
$B C$ \\
$A D$ \\
\end{tabular} & $\begin{array}{l}8210 \\
7350 \\
6570 \\
5630 \\
1640 \\
\end{array}$ & $\begin{array}{l}7600 \\
6830 \\
6230 \\
5470 \\
1960 \\
\end{array}$ & $\begin{array}{l}B C \\
B C \\
B C \\
B C \\
A D\end{array}$ & \begin{tabular}{|c|c|c|c|}
17 & 8 \\
13 & 8 \\
10 & 8 \\
11 & 8 \\
$x$ & 8 \\
\end{tabular} & $\begin{array}{l}8,20 \\
8,20 \\
8,20 \\
8,20 \\
8,20\end{array}$ \\
\hline 19 & \begin{tabular}{|l|} 
Kaukola \\
Rupunkangas \\
3
\end{tabular} & 32 & EM, cultural layer & burnt bone & Hela-1165 & 8740 & 80 & 7940 & 7610 & $B C$ & 8190 & 7590 & $\mathrm{BC}$ & $\left.11\right|^{8}$ & 8,20 \\
\hline 20 & Kirvu Harjula & 33 & LN, org, hearth & burnt bone & Hela-1176 & 3995 & 40 & 2570 & 2470 & $\mathrm{BC}$ & 2630 & 2350 & $B C$ & 162 & 21 \\
\hline 21 & Kirvu Juhola 2 & 34 & EM, bone pit & burnt bone & Hela-1164 & 8970 & 75 & 8280 & 7980 & $\mathrm{BC}$ & 8310 & 7840 & $\mathrm{BC}$ & $\left.16\right|^{2}$ & 21 \\
\hline 22 & \begin{tabular}{|l} 
Kirvu Kivimäki \\
2
\end{tabular} & 35 & EN, CW1, cultural layer & charcoal & Hela-1158 & 2380 & 35 & 510 & 390 & $B C$ & 730 & 380 & $\mathrm{BC}$ & \begin{tabular}{|l|l}
7 & 2 \\
\end{tabular} & 21 \\
\hline
\end{tabular}


Table 2. Continuation.

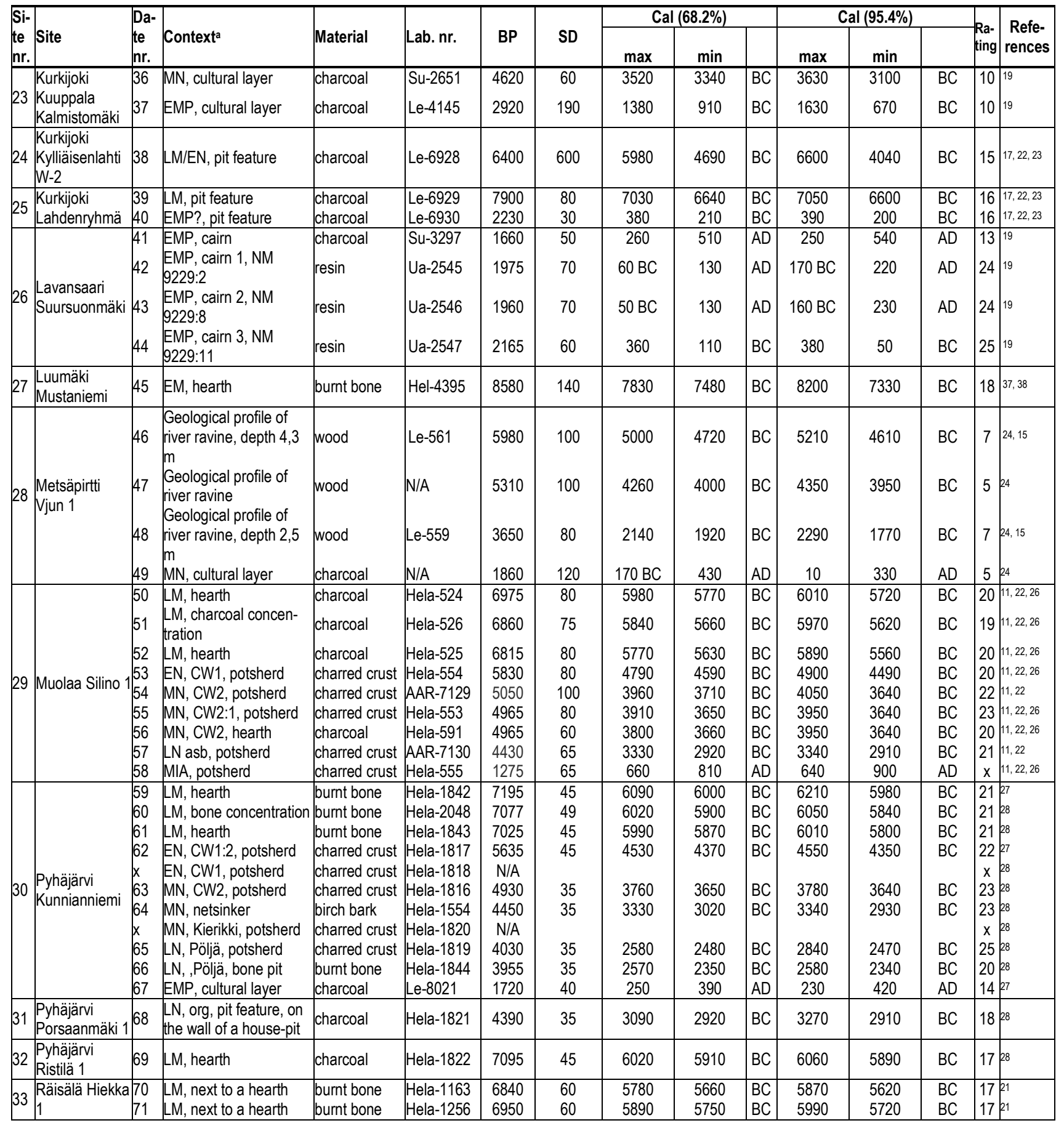


Table 2. Continuation.

\begin{tabular}{|c|c|c|c|c|c|c|c|c|c|c|c|c|c|c|c|}
\hline \multirow{2}{*}{$\begin{array}{l}\text { Si- } \\
\text { te } \\
\text { nr. }\end{array}$} & \multirow{2}{*}{ Site } & \multirow{2}{*}{$\begin{array}{l}\text { Da- } \\
\text { te } \\
\text { nr. }\end{array}$} & \multirow{2}{*}{ Contexta } & \multirow{2}{*}{ Material } & \multirow{2}{*}{ Lab. nr. } & \multirow{2}{*}{ BP } & \multirow{2}{*}{ SD } & \multicolumn{3}{|c|}{ Cal $(68.2 \%)$} & \multicolumn{3}{|c|}{ Cal $(95.4 \%)$} & \multirow{2}{*}{$\begin{array}{l}\text { Ra- } \\
\text { ting }\end{array}$} & \multirow{2}{*}{$\begin{array}{l}\text { Refe- } \\
\text { rences }\end{array}$} \\
\hline & & & & & & & & $\max$ & $\min$ & & $\max$ & $\min$ & & & \\
\hline \multirow{11}{*}{34} & \multirow{11}{*}{$\begin{array}{l}\text { Räisälä } \\
\text { Juoksemajärvi } \\
\text { Westend }\end{array}$} & 72 & LM, cultural layer & charcoal & Le-6556 & 7750 & 180 & 6990 & 6420 & $B C$ & 7080 & 6240 & BC & 11 & $\begin{array}{ll}10, & 11,22 \\
29,30 & \end{array}$ \\
\hline & & 73 & MN, cultural layer & charcoal & Le-6641 & 4550 & 180 & 3520 & 3020 & $B C$ & 3710 & 2770 & $B C$ & 18 & $\begin{array}{l}10,11,22, \\
29,30\end{array}$ \\
\hline & & 74 & LN, cultural layer & charcoal & Le-6512 & 4150 & 50 & 2880 & 2630 & $B C$ & 2890 & 2580 & $B C$ & 18 & $\begin{array}{l}10,11,22, \\
29,30\end{array}$ \\
\hline & & 75 & LN, cultural layer & charcoal & Le-6601 & 3740 & 90 & 2290 & 2020 & $B C$ & 2460 & 1930 & BC & 19 & $\begin{array}{l}10,11,22, \\
29,30\end{array}$ \\
\hline & & 76 & LN, cultural layer & charcoal & Le-6557 & 3700 & 320 & 2570 & 1690 & $B C$ & 3020 & 1320 & BC & 19 & $\begin{array}{l}{\left[\begin{array}{l}10,11,22, \\
29,30\end{array}\right.} \\
2,\end{array}$ \\
\hline & & 77 & $\begin{array}{l}\mathrm{LN} \text {, charcoal concentra- } \\
\text { tion next to a hearth in } \\
\text { the eastern half of a } \\
\text { house-pit }\end{array}$ & charcoal & Le-6602 & 3660 & 30 & 2130 & 1970 & $B C$ & 2140 & 1950 & $B C$ & 24 & $\begin{array}{l}10,11,22 \\
29,30\end{array}$ \\
\hline & & 78 & LN, cultural layer & charcoal & Le-6642 & 3450 & 100 & 1890 & 1630 & $B C$ & 2030 & 1520 & $B C$ & 20 & $\begin{array}{l}10,11,22, \\
29,30\end{array}$ \\
\hline & & 79 & $\begin{array}{l}\text { EMP, charcoal concen- } \\
\text { tration (hearth) in the } \\
\text { western corner of a } \\
\text { house-pit }\end{array}$ & charcoal & Le-6600 & 3370 & 30 & 1730 & 1620 & $B C$ & 1750 & 1530 & $B C$ & 23 & $\begin{array}{l}10,11,22 \\
29,30\end{array}$ \\
\hline & & 80 & EMP, cultural layer & charcoal & Le-6643 & 2620 & 70 & 900 & 600 & $B C$ & 930 & 530 & BC & 8 & $\begin{array}{l}10,11,22, \\
29,30\end{array}$ \\
\hline & & 81 & MIA?, cultural layer & charcoal & Le-6640 & 1400 & 50 & 600 & 670 & $A D$ & 540 & 770 & $A D$ & 9 & $\begin{array}{l}10,11,22 \\
29,30\end{array}$ \\
\hline & & $x$ & LN?, cultural layer & charcoal & Le-6558 & $N / A$ & & & & & & & & $\mathrm{x}$ & 29 \\
\hline \multirow{3}{*}{35} & \multirow{3}{*}{$\begin{array}{l}\text { Räisälä Hovi } \\
\text { Kalmistomäki }\end{array}$} & 82 & $\begin{array}{l}\text { EMP, potsherd, NM } \\
2556\end{array}$ & charred crust & Hela-8 & 2360 & 70 & 740 & 370 & $B C$ & 760 & 230 & $B C$ & 20 & 12,19 \\
\hline & & 83 & $\begin{array}{l}\text { EMP, potsherd, NM } \\
6675: 42\end{array}$ & charred crust & Hela-466 & 2640 & 70 & 900 & 760 & $B C$ & 980 & 540 & $\mathrm{BC}$ & 23 & 19,31 \\
\hline & & 84 & $\begin{array}{l}\text { EMP, potsherd, NM } \\
6675: 50\end{array}$ & & Hela-469 & 2540 & 75 & 800 & 540 & $B C$ & 820 & 410 & $\mathrm{BC}$ & 23 & 19,31 \\
\hline 36 & $\begin{array}{l}\text { Räisälä Kuuse- } \\
\text { la }\end{array}$ & 85 & LM, cultural layer & burnt bone & Hela-1175 & 7945 & 60 & 7030 & 6700 & $B C$ & 7050 & 6660 & $B C$ & & 21 \\
\hline 37 & $\begin{array}{l}\text { Räisälä Peltola } \\
\text { C }\end{array}$ & 86 & $\begin{array}{l}\text { MN, CW2, wall of a } \\
\text { pithouse }\end{array}$ & $\begin{array}{l}\text { resin "chew- } \\
\text { ing gum" c }\end{array}$ & Hela-1159 & 4905 & 45 & 3720 & 3640 & $B C$ & 3790 & 3630 & $\mathrm{BC}$ & & 21 \\
\hline 38 & $\begin{array}{l}\text { Viipuri } \\
\text { Häyrynmäki }\end{array}$ & 87 & $\begin{array}{l}\text { MN, CW3, potsherd, } \\
\text { NM 5620:CCXLIV }\end{array}$ & birch bark tar & Hela-358 & 4550 & 60 & 3370 & 3100 & $B C$ & 3500 & 3020 & $\mathrm{BC}$ & 21 & 12,19 \\
\hline \multirow{4}{*}{39} & & 88 & LM, cultural layer & charcoal & Le-7538 & 7580 & 50 & 6480 & 6400 & $B C$ & 6570 & 6270 & $\mathrm{BC}$ & & 13 \\
\hline & Viipuri & 89 & LM, cultural layer & charcoal & Le-7539 & 7220 & 50 & 6210 & 6010 & $B C$ & 6220 & 6010 & $\mathrm{BC}$ & 20 & 13 \\
\hline & Ozernoe 3 & 90 & LM, cultural layer & charcoal & Le-7540 & 7680 & 50 & 6590 & 6460 & $B C$ & 6630 & 6440 & BC & 20 & 13 \\
\hline & & 91 & LM, cultural layer & charcoal & Le-7541 & 7640 & 50 & 6570 & 6430 & $B C$ & 6600 & 6420 & $\mathrm{BC}$ & 20 & 13 \\
\hline \multirow{3}{*}{40} & \multirow{3}{*}{$\begin{array}{l}\text { Virolahti } \\
\text { Meskäärtty }\end{array}$} & 92 & $\begin{array}{l}\text { MN, CW3, potsherd, } \\
\text { NM 37112:1 }\end{array}$ & charred crust & Hela-1613 & 4535 & 35 & 3360 & 3110 & $B C$ & 3370 & 3100 & $B C$ & 23 & 36 \\
\hline & & 93 & $\begin{array}{l}\text { MN, CW3, potsherd, } \\
\text { NM 37112:3 }\end{array}$ & charred crust & Hela-1615 & 4520 & 40 & 3350 & 3110 & $B C$ & 3370 & 3090 & $\mathrm{BC}$ & 23 & 36 \\
\hline & & 94 & $\begin{array}{l}\text { LN, cord, potsherd; NM } \\
37112: 2\end{array}$ & charred crust & Hela-1614 & 3820 & 45 & 2350 & 2150 & $B C$ & 2460 & 2140 & $\mathrm{BC}$ & & 36 \\
\hline
\end{tabular}

${ }^{a} E M=$ Early Mesolithic, $L M=$ Late Mesolithic, EN= Early Neolithic, $M N=$ Middle Neolithic, $L N=$ Late Neolithic, EMP= Early Metal Period, MIA= Middle Iron Age

${ }^{b} N M=$ National Museum of Finland catalogue number

cErroneously reported as burnt bone by Halinen and Mökkönen (2009).

All the presented dates have been calibrated with OxCal 4.0 (Bronk Ramsey 2001), using the IntCal09 calibration curve for the Northern Hemisphere (Reimer et al. 2009).

References: 1) Jungner 1979: 44; 2) Siiriäinen 1974; 3) Matiskainen 1989: 71; 4) Carpelan 2008; 5) Miettinen et al. 2008; 6) Takala 2004: 151; 7) Ylikoski 2004: 25; 8) Lisitsyn and Gerasimov 2008; 9) Takala 2004: 161; 10) Gerasimov et al. 2003; 11) Timofeev et al. 2004a; 12) Takala 2004: 156; 13) Sapelko et al. 2008; 14) Vereščagina 2003; 15) Timofeev and Zaitseva 1991; 16) Carpelan et al. 2008; 17) Nordqvist et al. 2008; 18) Lisitsyn 2003; 19) Saarnisto (ed) 2003: 512; 20) Mökkönen et al. 2007; 21) Halinen and Mökkönen 2009; 22) Gerasimov and Kul'kova 2003; 23) Seitsonen and Gerasimov 2008; 24) Rudenko 1970; 25) Timofeev et al. 2004b; 26) Takala and Sirviö 2003; 27) Seitsonen et al. 2009; 28) this paper; 29) Halinen et al. 2008; 30) Timofeev et al. 2003; 31) Lavento 2001: 102; 32) Pesonen 2004; 33) Huurre 2003: 234; 34) Jussila \& Matiskainen 2003; 35) Jussila et al. 2007; 36) Mökkönen 2008; 37) Luoto \& Laakso 2001; 38) Hakulinen 2003 


\section{ARCHAEOLOGICAL RADIOCARBON DATES}

In the following the radiocarbon dates assessed as "Good" or "Weird" are presented according to the major chronological periods. The used archaeological sequence and chronological contexts are shown in Table 3, compiled on the basis of various studies in Finland and NorthWest Russia, and adapted to the local conditions; we especially consider it more appropriate to date the start of Late Neolithic at 3000 cal BC (see also Lang \& Kriiska, 2001), since there are more changes around that time, than at the often used 2300 cal BC (e.g. Carpelan 1999; Mökkönen 2011). The beginning of (Sub)Neolithic period in the area is traditionally connected to the appearance of ceramic manufacture; however, recent studies suggest that the introduction of agriculture might actually date older than previously thought, at least to the Middle Neolithic, and needs revision in the future (Mökkönen 2010).

Table 3. Chronological contexts of the ${ }^{14} \mathrm{C}$ dates; in the local terminology Neolithic refers to the appearance of ceramic manufacture.

\begin{tabular}{lccc}
\hline \multirow{2}{*}{ Period } & \multirow{2}{*}{ cal BC/AD } & \multicolumn{2}{c}{${ }^{14}$ C dates } \\
\cline { 3 - 4 } & & Total & $\%$ \\
\hline Early Mesolithic & $8600-7000$ & 12 & $15 \%$ \\
Late Mesolithic & $7000-5100$ & 18 & $22 \%$ \\
Early Neolithic & $5100-4000$ & 7 & $9 \%$ \\
Middle Neolithic & $4000-3000$ & 14 & $17 \%$ \\
Late Neolithic & $3000-1800$ & 16 & $20 \%$ \\
Early Metal Period & $1800-A D 300$ & 14 & $17 \%$ \\
\hline
\end{tabular}

\section{Early Mesolithic (8600-7000 cal BC)}

The earliest presence of humans in the study area relates to the post-glacial pioneer settlement, dated in South Finland to ca. $8850-8400 \mathrm{cal} \mathrm{BC}$ (e.g. Takala, 2004). The oldest known dwelling site is Joutseno Saarenoja 2, dated to $8710-8450$ cal BC $^{5}$ (Hela-728: $9310 \pm 75 \mathrm{BP}$ ) (Jussila et al., 2007) (Fig. 3). A coeval ${ }^{14} \mathrm{C}$ dating, $8640-8320 \mathrm{cal}$ BC, comes from Antrea Suuri Kelpojärvi site (Hela-931: 9270 \pm 120 BP) (Takala, 2004; Jussila et al., 2007), located a few kilometers away from the find location of the famous Antrea Korpilahti Net Find, excavated in 1914 (Pälsi, 1920b). The most recent ${ }^{14} \mathrm{C}$ sample from the willow braid of this net gave a date $8560-8240$ cal BC (Hela404: $9140 \pm 135 \mathrm{BP}$ ), slightly younger than the previous ones obtained from the pine bark floats (Hel-1303: 9310 \pm 140 BP, Hel-269: 9230 \pm 210 BP); these were most likely affected by the "old wood" effect, suggesting the pine(s) used for the floats had a considerable own age already at the time when the net was weaved (Carpelan, 2008; Miettinen et al., 2008).

Early Mesolithic habitation subsequent to the initial pioneer settlement is evidenced from six dated sites. The oldest of these is Kirvu Juhola 2, where a sample from a pit full of burnt bone fragments was dated to 8280-7980 cal BC (Hela-1164: 8970 \pm 75 BP) (Halinen and Mökkönen, 2009). Two sites excavated in the Heinjoki area, Valklampi 1 and 2, date slightly younger (Hela-743: 8765 \pm 65 BP, Hela-744: 8720 \pm 70 BP) (Takala, 2004). From Luumäki Mustaniemi, located by the nowadays dry ancient Lake Selänalajärvi, a burnt bone sample was dated to 7830-7480 cal BC (Hela-4395: 8580 140 BP) (Luoto and Laakso, 2001; Hakulinen, 2003).
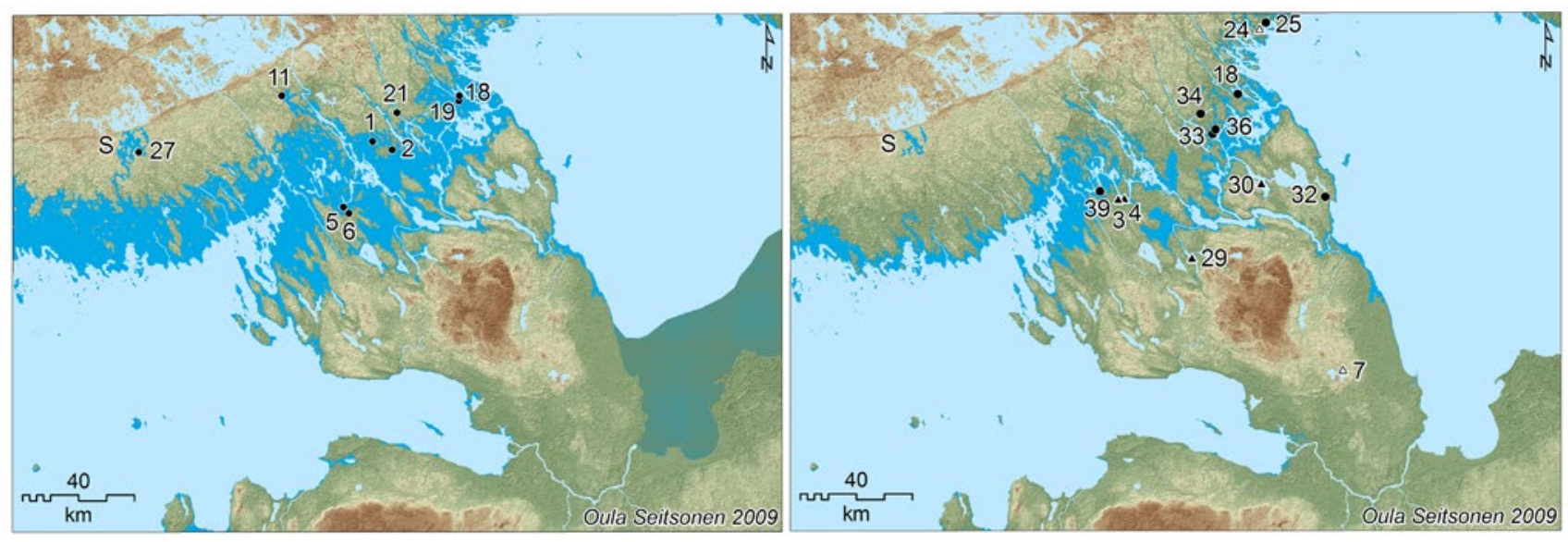

Fig. 3. Distribution of ${ }^{14} \mathrm{C}$ dated sites; Left: Early Mesolithic sites, darker blue water levels are reconstructed to the Ancylus transgression maximum ca. 8400-8300 cal BC, rasterizing in the southern Lake Ladoga shows the area now submerged by the lake; Right: Late Mesolithic and Early Neolithic sites (black dot $=$ Late Mesolithic, black triangle $=$ both Late Mesolithic and Early Neolithic, open triangle $=$ Late Mesolithic and possible Early Neolithic), water levels reconstructed to ca. 5000 cal BC; S=ancient Lake Selänalajärvi (also in Figs. 5-6). Site numbers in all maps refer to Table 2 (Map: O. Seitsonen).

\footnotetext{
5 One sigma (68.2\%) distributions are used in the text (e.g Michczyński, 2007).
} 
Contemporaneous Early Mesolithic dates were obtained from two adjacent sites in Kaukola: burnt bones collected from Kaukola Rupunkangas 3 (Hela-1165: $8740 \pm 80$ BP) (Fig. 4: 1-3) and the oldest habitation phase of Kaukola Rupunkangas 1A (Hela-1182: 8770 \pm 85 BP) (Fig. 4: 4-7) date to the interval $8170-7610$ cal BC (Mökkönen et al., 2007: 20). The latter date derives from charcoal sampled in the lowest cultural deposits inside a house-pit, and hence dates the oldest known dwelling of this kind in the Karelian Isthmus. This house-pit was reused several times in the Mesolithic, based on one more

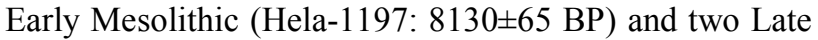
Mesolithic radiocarbon dates (Hela-1196: 7550 75 BP,
Hela-1195: $6596 \pm 55$ BP), as well as during the Middle Neolithic and Early Metal Period based on the find material (Mökkönen et al., 2007).

\section{Late Mesolithic (7000-5100 cal BC)}

Besides Rupunkangas 1A, reliable Late Mesolithic dates have been obtained from eight sites (Fig. 3). Charcoal from the cultural layer at Räisälä Kuusela site gave a dating 7030-6700 cal BC (Hela-1175: 7945 \pm 60 BP) (Halinen and Mökkönen, 2009), and a pit feature at the multiperiod site Kurkijoki Lahdenryhmä was dated to 70306640 cal BC (Le-6929: 7900 \pm 80 BP); the Mesolithic
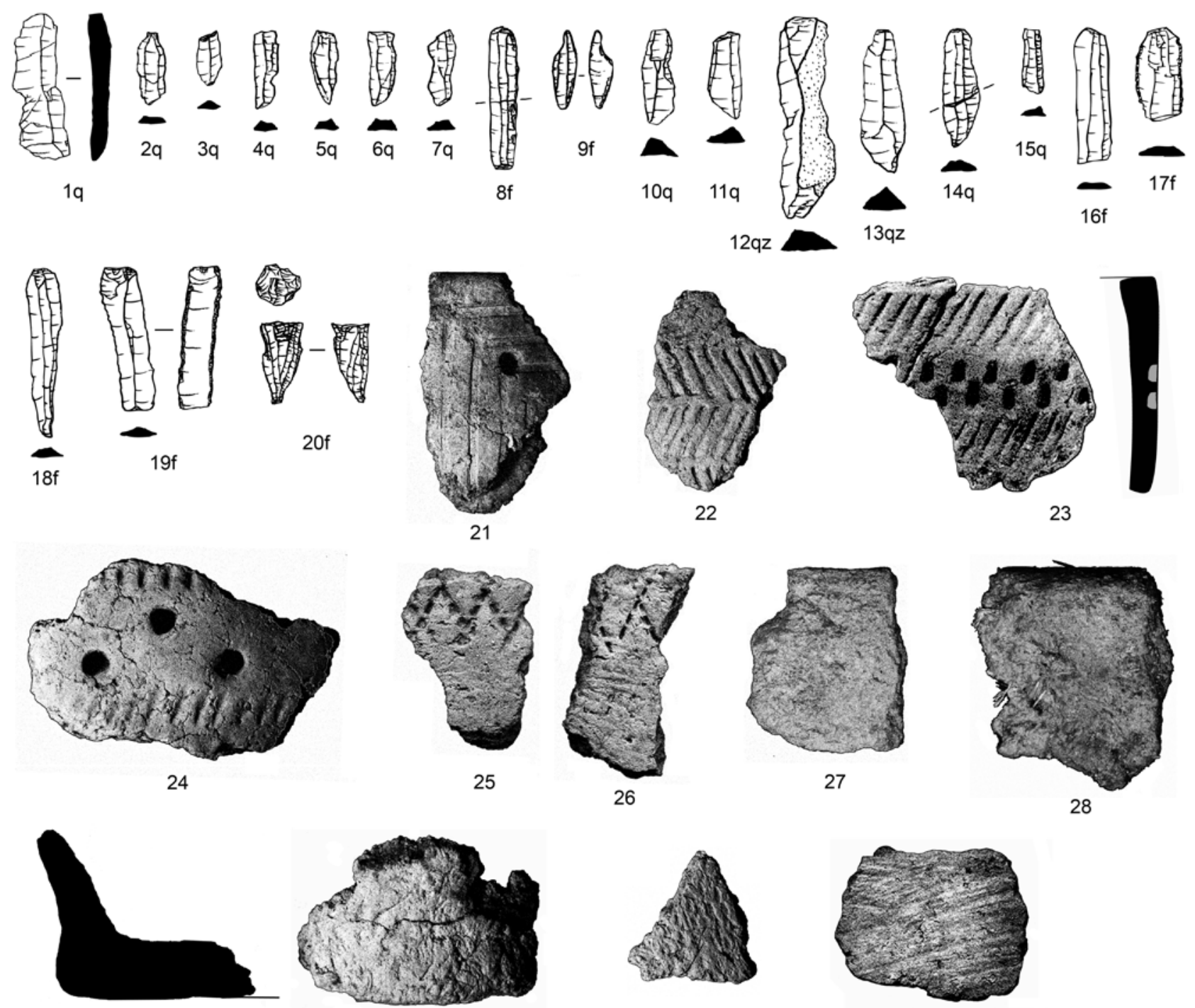

29

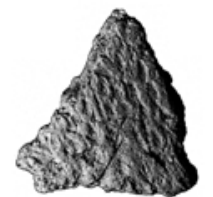

30

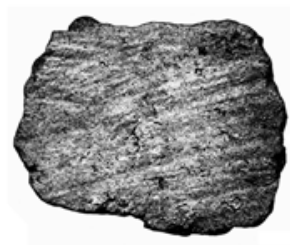

31

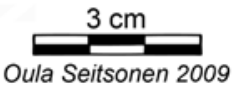

Fig. 4. Finds from radiocarbon dated sites: Mesolithic: 1-17) blades and microblades, 8, 9 and 17 retouched; Mesolithic (?): 18-19) microblades, 19 retouched, 20) conical microblade core; CW1: 21-22; CW2: 23-24; CW3: 25-26; Kierikki/Pöljä ceramics: 27-28; Late Neolithic organic-tempered ceramics: 29-30; Early Metal Period ceramics: 31. Site numbers in parentheses refer to Table 2: 1-3 (19), 4-7 (18), 8-9 (34), 10-13 (30), 14-15 (29), 16-17 (33), 18-20 (7), 21-22 (30), 23 (29), 24 (30), 25-26 (31), 27-28 (30), 29-30 (30), 31 (30) (q=quartz, qz=quartzite, f=flint) (Illustration: O. Seitsonen). 
finds at this site are covered by Neolithic and possibly Early Metal Period cultural layers (Seitsonen and Gerasimov, 2008). Excavations at the multi-period site Räisälä Juoksemajärvi Westend produced a large number of ${ }^{14} \mathrm{C}$ dates: the oldest of these, $6990-6420$ cal BC (Le6556: $7750 \pm 180 \mathrm{BP})$ shows, in accordance with the find material (Fig. 4: 8-9), that the habitation started in the Mesolithic (Halinen et al., 2008). From Viipuri Ozernoe 3 site comes a series of dates from Mesolithic context, ranging from 6590 to $6010 \mathrm{cal} \mathrm{BC}$ (Le-7540: 7680 \pm 50 BP, Le-7541: $7640 \pm 50$ BP, Le-7538: $7580 \pm 50$ BP, Le7539: $7220 \pm 50 \mathrm{BP}$ ), covered by alluvial sediments and also by Neolithic layers (Sapelko et al., 2008).

One of the most interesting sites discovered lately in the Karelian Isthmus is the deeply stratified multi-period dwelling site Pyhäjärvi Kunnianniemi, with nearly three meters thick prehistoric deposits (Gerasimov et al., 2007; 2008; Seitsonen and Nordqvist, 2009; Seitsonen et al., 2009). The uniqueness of the site lies in its four distinctive cultural layers, each sealed by a sterile transgression layer. From the lowermost cultural layer two Mesolithic fireplaces were dated, and the results evidence successive use of these hearths between 6090-5870 cal BC (Hela1842: $7195 \pm 45$ BP, Hela-1843: $7025 \pm 45$ BP) (Fig. 4: 1013) (Seitsonen et al., 2009). Parallel date was obtained from burnt bone collected inside a possible Mesolithic house-pit in another trench (Hela-2048: 7077 \pm 49 BP). To the same time period belongs also a date obtained from charcoal sampled in a hearth at Pyhäjärvi Ristilä 1 site (Hela-1822: 7095 \pm 45 BP).

Besides Kunnianniemi, cultural layers separated by transgression layers have been studied at another deeply stratified site, Muolaa Telkkälä Silino. Three dates, alongside finds (Fig. 4: 14-15), show that the habitation began also here during the Late Mesolithic (Hela-524: 6975 \pm 80 BP, Hela-526: 6860 75 BP, Hela-525: 6815 \pm 80 BP) (Takala and Sirviö, 2003). Räisälä Hiekka 1 site produced also two contemporaneous dates from burnt bones (Hela-1256: 6950 \pm 60 BP, Hela-1163: 6840 \pm 60 BP) (Halinen and Mökkönen, 2009) (Fig. 4: 16-17).

Finally, a pit-feature excavated in 2003 at multiperiod site Kurkijoki Kylliäisenlahti W-2 was dated close to the end of Late Mesolithic, 5980-4690 cal BC (Le6928: 6400 \pm 600 BP) (Seitsonen and Gerasimov, 2008). However, due to the large standard deviation this date may as well be connected to the subsequent Early Combed Ware (CW1) habitation at the site.

\section{Early Neolithic (5100-4000 cal BC)}

The earliest, and somewhat dubious, dates mentioned in connection to Early Neolithic come from multi-period site Hepojärvi, where two hearths were dated to 5490-

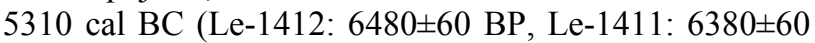
BP) (Vereščagina, 2003: 149; Timofeev et al., 2004a). The earliest certain Neolithic dates derive from charred crust on CW1 sherds: from Muolaa Silino, 4790-4590 cal BC (Hela-554: 5830 \pm 80 BP) (Takala and Sirviö, 2003), and from Pyhäjärvi Kunnianniemi, 4530-4370 cal BC (Hela-1817: 5635 45 BP) (Seitsonen et al., 2009) (Fig. 4: 21-22). Two multi-period sites in the Heinjoki area also exhibit CW1 dates: Tarhojenranta $(5815 \pm 50$ BP [no laboratory number reported]) (Takala, 2004: 156), and Latukangas 1 (Le-6511: 5770 \pm 130 BP) (Timofeev et al., 2004a).

Both the crust dates from Silino and Kunnianniemi and the context dates from Heinjoki sites fit well within the proposed dating of CW1: the appearance of earliest pottery in the Karelian Isthmus and Southern Finland has been commonly dated to ca. 5200-5100 cal BC (Carpelan, 1999; Carpelan et al., 2008). However, the two context dates from Hepojärvi are relatively early for $\mathrm{CW} 1$. Some researchers have hypothesized that these dates suggest the diffusion of CW1 through the Karelian Isthmus to Finland from the present-day Republic of Karelia (Timofeev et al., 2004a), where it appears by 5400 cal BC (e.g. German, 2004). There is also a synchronous radiocarbon date, 5550-5060 cal BC (Le-405: $6380 \pm 220 \mathrm{BP})$, tentatively linked to CW1 from the Ust'Rybežna 1 site on the southern end of Lake Ladoga (Gurina, 1961; Gerasimov and Subetto, 2009). Still, direct evidence for an earlier appearance of ceramics in the Karelian Isthmus, such as crust dates, is missing so far. Conversely, the few hundred years older dates from CW1 contexts at Hepojärvi, Ust'-Rybežna 1 and possibly also at Kurkijoki Kylliäisenlahti W-2 might derive from the "old wood" effect, as these are all made from charcoal of indefinite taxa. It is also possible that the Hepojärvi dates relate to a Mesolithic habitation phase, as suggested by some finds (Fig. 4: 18-20) (also Vereščagina, 2003).

\section{Middle Neolithic (4000-3000 cal BC)}

${ }^{14} \mathrm{C}$ dates connected to the Typical Combed Ware (CW2) are present from four sites, including four crust dates of pottery (Fig. 5). The oldest dates, calibrated to the interval 3960-3650 cal BC, come from two CW2 sherds found at Muolaa Silino site (AAR-7129: 5050 \pm 100 BP, Hela-553: 4965 \pm 80 BP) (Takala and Sirviö, 2003; Timofeev et al. 2004a; Fig. 4: 23). Synchronous with these are a third date from Silino, from hearth charcoal (Hela-591: 4965 \pm 60 BP) (Takala and Sirviö, 2003), and a crust date from the second cultural layer at Pyhäjärvi Kunnianiemi, 3760-3650 cal BC (Hela1816: 4930 \pm 35 BP; Fig. 4: 24). Practically contemporaneous is also a date from Räisälä Peltola $\mathrm{C}$ site, made of resin "chewing gum" found from the wall of a CW2 house-pit, 3720-3640 cal BC (Hela-1159: 4905 \pm 45 BP; Halinen and Mökkönen, $\left.2009^{6}\right)$. The last ${ }^{14} \mathrm{C}$ dated CW2 sherd from Johannes Tokarevo 1:1 site gave a dating 3930-3340 cal BC (Ki-10298: 4790 \pm 210 BP; Lisicyn, 2003); however, due to the large standard deviation the calibrated age range covers nearly the whole Middle Neolithic period. All these dates are in accordance with

${ }^{6}$ Erroneously reported as burnt bone by Halinen and Mökkönen (2010). 

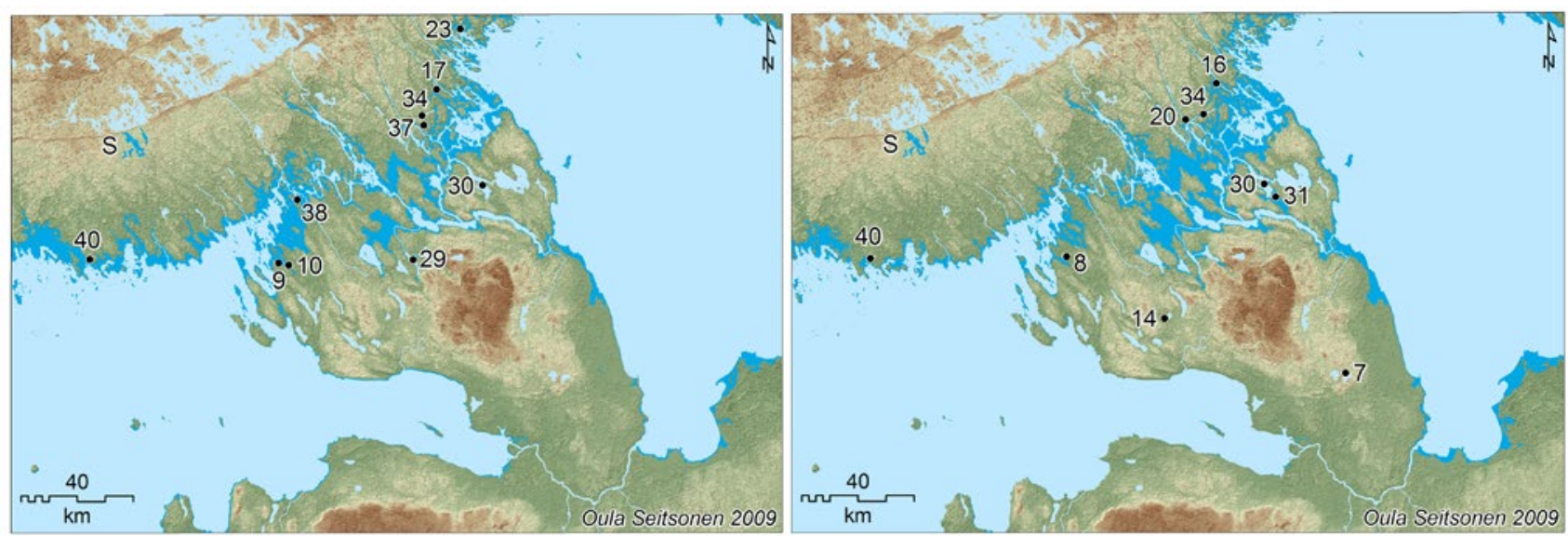

Fig. 5. Distribution of ${ }^{14} \mathrm{C}$ dated sites; Left: Middle Neolithic sites, darker blue water levels are reconstructed to ca. $4000 \mathrm{cal}$ BC; Right: Late Neolithic sites, water levels reconstructed to the Lake Ladoga transgression maximum period ca. 1350 cal BC (Map: O. Seitsonen).

the CW2 period in Finland, dated to ca. 3950-3500/3400 cal BC (Pesonen, 2004; Tallavaara et al., 2010).

The number of dates connectable to Late Combed Ware (CW3), partly overlapping with CW2, is less clearcut. Birch bark pitches on sherds of CW3 excavated already in the early $20^{\text {th }}$ century at multi-period sites Kaukola Kyöstälänharju (Pälsi, 1920a) and Viipuri Häyrynmäki (e.g. Huurre, 2003; Seitsonen, 2004) gave dates 3650-3380 cal BC and 3370-3100 cal BC, respectively (Hela-359: 4780 \pm 70 , Hela-358: 4550 \pm 60 BP; Pesonen, 2004). Two more crust dates of CW3 sherds, collected at Virolahti Meskäärtty site, are contemporaneous with the Häyrynmäki sample (Hela-1613: 4535 \pm 35 , Hela-1615: $4520 \pm 40$ BP; Mökkönen, 2008). Oldest radiocarbon date from the multi-period site Kurkijoki Kuuppala Kalmistomäki, made of charcoal collected from Stone Age context during excavation of Iron Age burials, belongs to the CW2-CW3 phase as also suggested by the finds ( $\mathrm{Su}-$ 2651: 4620 \pm 60 BP) (Saarnisto (ed.), 2003).

It is perhaps notable that apart from Kyöstälänharju date, all other $\mathrm{CW} 3{ }^{14} \mathrm{C}$ age determinations are relatively late when compared with the Finnish material, ${ }^{14} \mathrm{C}$ dated to ca. 3750-3200 cal BC (Pesonen, 2004). According to a chronology not strictly based on radiometric dates, CW3 seems to have stayed in use until ca. $2800 \mathrm{cal}$ BC (Carpelan, 1999), and on the grounds of data from Estonia CW3 might have been used even longer (Lang and Kriiska, 2001). This idea might be supported by even younger context dates from the study area connectable to ceramics resembling CW3 (see below).

Asbestos and organic tempers of ceramics become common from the Middle Neolithic on, although they are visible already in the Early Neolithic times, also in the current study area (e.g. Edgren, 1966; Pesonen, 1996). The oldest dating of asbestos-tempered pottery in the Karelian Isthmus comes from multi-period site Johannes Väntsi, studied before World War II (Carpelan et al., 2008), where crust on a sherd of Kierikki Ware gave a result 3770-3530 cal BC (Hela-465: 4870 \pm 85 BP; Huurre, 2003). This date is slightly earlier than the dating of Kierikki Ware in Finland, ca. 3650-3100 cal BC (Pesonen, 2004; Tallavaara et al., 2010). The only other undisputed ${ }^{14} \mathrm{C}$ dated Kierikki context is at Pyhäjärvi Kunnianniemi, where the birch bark cover of a net sinker from a context with asbestos- and organic-tempered Kierikki-like ceramics was dated to $3330-3020$ cal BC (Hela-1554: 4450 \pm 35 BP; Fig. 4: 27).

\section{Late Neolithic (3000-1800 cal BC)}

The earliest dating connected to the Late Neolithic Pöljä tradition in the Karelian Isthmus comes from Muolaa Silino, where charred crust on an asbestostempered sherd was dated to $3330-2920 \mathrm{cal}$ BC (AAR7130: 4430 \pm 65 BP) (Timofeev et al., 2004a) (Fig. 5). Like the Väntsi date for Kierikki, also this is a relatively early age for Pöljä, dated in Finland ca. 3250-2500/1900 cal BC (Pesonen, 2004; Tallavaara et al., 2010). More dates come from Pyhäjärvi Kunnianniemi, where crust on another sherd of Pöljä Ware, found on the floor-level of a Late Neolithic house-pit, was dated to 2580-2480 cal BC (Hela-1819: 4030 \pm 35 BP), with a synchronous date obtained from a concentration of burnt bones right outside this house-pit (Hela-1844: 3955 \pm 35 BP; Fig. 4: 28).

Besides the Mesolithic finds, artefacts suggestive of at least Middle and Late Neolithic occupation were unearthed from the house-pit studied in toto at Räisälä Juoksemajärvi Westend (Gerasimov and Kul'kova, 2003; Halinen et al., 2008). Kierikki/Pöljä period habitation is supported by a few pieces of asbestos-tempered ceramics collected next to the studied dwelling and two ${ }^{14} \mathrm{C}$ dates, 3520-3020 cal BC and 2880-2630 cal BC (Le-6641: 4550 \pm 180 BP, Le-6512: 4150 \pm 50 BP; Halinen et al., 2008); both dates derive from charcoal collected in the Neolithic cultural layer outside the house-pit. The Late Neolithic-Early Metal Period use of the house-pit is supported by a series of radiocarbon dates (Le-6601: 
3740 \pm 90 BP, Le-6557: 3700 \pm 320 BP, Le-6602: 3660 \pm 30 BP, Le-6642: $3450 \pm 100$ BP, Le-6600: $3370 \pm 30$ BP). Of these, two dates from its floor level, Le-6600 dating a hearth in the western corner of floor and Le-6602 dating a charcoal concentration next to a hearth in its eastern part, suggest the last use-stage of the house-pit dates most likely between $2130-1620$ cal BC; the other dates derive from the cultural layer in- and outside the house-pit (Gerasimov and Kul'kova, 2003; Halinen et al., 2008). Therefore dating the dwelling to the Early Neolithic, as hypothesized earlier by some researchers, seems conjectural (Timofeev et al., 2004a; Mökkönen 2009) ${ }^{7}$.

Corded Ware, as such a rather rare occurrence in the Karelian Isthmus, is represented by three dates. The oldest of these, 2870-2620 cal BC (Hela-468: 4130 \pm 60 BP; Saarnisto (ed.), 2003), comes from crust on a pottery sherd found at the multi-period dwelling site Kaukola Lavamäki in the early $20^{\text {th }}$ century (Pälsi, 1920a), the second, 2460-2230 cal BC (Hela-663: 3860 45 BP), from hearth charcoal at Johannes Loikas site (Carpelan et al., 2008), and the third, 2350-2150 cal BC (Hela-1614: $3820 \pm 45$ BP) from crust on a sherd at Virolahti Meskäärtty (Mökkönen, 2008). It is perhaps significant, that the youngest dated sherd bears resemblance to the Late Corded Ware of Estonia (Mökkönen, 2008), where this ceramic tradition might continue until 1800 cal BC (Lang and Kriiska, 2001).

There is a number of Late Neolithic ${ }^{14} \mathrm{C}$ dates connected to organic-tempered ceramics. A date 3090-2920 cal BC (Hela-1821: 4390 \pm 35 BP) was obtained from charcoal collected in a pit feature on the wall of a large house-pit connected to organic- and sand-tempered, comb stamp decorated CW3-like pottery at the multi-period site Pyhäjärvi Porsaanmäki 1 (Fig. 4: 25-26). Also Hepojärvi site includes CW3-like organic-tempered ceramics, and a hearth and a pit feature from this context were dated to 2860-2570 cal BC and 2840-2460 cal BC, respectively (Le-1410: $\quad 4100 \pm 60 \quad$ BP, Le-1408: $4020 \pm 70 \quad$ BP) (Vereščagina, 2003; Timofeev et al., 2004a). One more date apparently connected to a CW3-like context comes from a hearth at Kirvu Harjula site, 2570-2470 cal BC (Hela-1176: 3995 40 BP; Halinen and Mökkönen, 2009). Organic-tempered ceramics dated close to the end of Late Neolithic period were also collected at Kanneljärvi 2 site: two charcoal samples gave results 2470-2340 and 18901770 cal BC (Le-2549: 3890 \pm 40 BP, Le-2550: 3500 \pm 40 BP; Gerasimov et al., 2003: 16; Timofeev et al., 2004a).

Even though the above dates are late for CW3 when compared to the chronology used in Finland, both in

\footnotetext{
${ }^{7}$ In our opinion the linking of the house-pit with CW1 habitation is based on over-emphasizing the role of one unambiguous and two uncertain CW1 sherds found inside the house-pit, and a CW1 vessel broken in situ on a lower terrace. Although the finds connectable to Late Neolithic occupation within the house-pit are also few, we see that the Late Neolithic-Early Metal Period dating is more plausible in the light of stratigraphy and the scrutiny of the contexts of ${ }^{14} \mathrm{C}$ dates, deriving from hearths on the floor level - of course it is possible that the house-pit was used already earlier, but there remains no visible indication of that.
}

Estonia and in the Republic of Karelia the use of Combed Ware has been reported to continue to $2500 \mathrm{cal} \mathrm{BC}$, or even later (Žul'nikov, 2005; Lang, 2006; Kriiska and Tvauri, 2007; also Mökkönen, 2008). However, the question of chronological and typological position(s) of the ceramics dating to the Late Neolithic and Early Metal Period boundary in the Karelian Isthmus remains open (Fig. 4: 29-30). The local Late Neolithic ceramics are so far badly studied, and the material is yet too fragmentary for classification(s). At this point it suffices to say, that the postulated similarities with some ceramic types found in Finland, Estonia and North-West Russia, like the asbestos- and organic-tempered ceramics of the Republic of Karelia (e.g. Žul'nikov, 2005) and Volosovo-tradition of the Volga-Oka region (e.g. Krajnov, 1987; Vikkula, 1984), are under investigation by the authors.

\section{Early Metal Period (1800 cal BC-300 cal AD)}

The transition from Late Neolithic to Early Metal Period is so far poorly understood: to the transitional period belong the above-mentioned dates from Räisälä Juoksemajärvi Westend and Kanneljärvi 2. The subsequent Textile Ware period is represented by four radiocarbon dates. A crust date from multi-period site Kaukola Kankaanmäki, 1430-1260 cal BC (Hela-467: 3085 \pm 70 BP; Lavento, 2001; 2003; also Pälsi, 1920a), belongs to the older part of the tradition, as is customary for the ${ }^{14} \mathrm{C}$ dates of Finnish and Karelian Textile Ware (Lavento, 2001; Fig. 6). A charcoal sample from an Early Metal Period context at Kurkijoki Kuuppala Kalmistomäki gave a date of 1380-910 cal BC (Le-4145: 2920 190 BP; Saarnisto (ed.), 2003); however, it has a large standard deviation and might be affected by "old wood" effect. Thus it might belong to the temporal context presented by two more crust dates on Textile Ware sherds from Räisälä Hovi Kalmistomäki, one of the classical sites for the Early Metal Period studies (e.g. Meinander, 1954). These dates, 900-760 cal BC and 800-540 cal BC (Hela-466: 2640 \pm 70 BP, Hela-469: $2540 \pm 75$ BP $)^{8}$, represent the later phase of the tradition (so called Kalmistomäki group), and are some of the youngest for Textile Ware (Lavento, 2001 ; 2003) - the Textile Ware is troublesome to date, but is given frames 1900/1700-500/0 cal BC (Lavento, 2001).

A crust date from a sherd of Luukonsaari Ware, 740370 cal BC (Hela-8: 2360 \pm 70 BP) (Uino, 1997; Lavento, 2003), further evidences the Early Metal Period habitation at Räisälä Hovi Kalmistomäki. Luukonsaari Ware was in use during the $1^{\text {st }}$ millennium $\mathrm{BC}$, and possibly until 500/600 AD (Lavento, 2001). Analogous date was obtained of charcoal from the Early Metal Period cultural

\footnotetext{
${ }^{8}$ Possibly due to a mix-up caused by similar site names, these dates have been in some accounts (Lavento 2001: 102, Fig. 6.11; Saarnisto (ed.) 2003: 512) connected to Kurkijoki Kuuppala Kalmistomäki site yet based on the catalogue number (National Museum of Finland; NM 6675), the dated sherds derive from Räisälä Hovi Kalmistomäki, as also reported by Lavento (2003: endnote 166).
} 
layer at Heinjoki Latukangas 1 site (Le-6559: 2400 \pm 50 BP) (Timofeev and Gerasimov, 2003; Timofeev et al., 2004a). Charcoal from the uppermost cultural layer of Kurkijoki Lahdenryhmä site was dated to 380-210 cal BC (Le-6930: 2230 $\pm 30 \mathrm{BP}$ ); few tiny ceramic fragments encountered in this context were tentatively interpreted as Late Neolithic, but the context might as well be connected to the Early Metal Period, since only a small test pit has been opened this far (Seitsonen and Gerasimov, 2008). The youngest date evidencing Early Metal Period habitation derives from Pyhäjärvi Kunnianniemi, where charcoal from the uppermost cultural layer was dated to 250-390 AD (Le-8021: 1720 440 BP, Seitsonen et al., 2009; Fig. 4: 31).

Finally, four dates from Lavansaari Suurisuonmäki, located in the middle of Gulf of Finland, originate from entirely different context than the other material presented in this paper: dates were obtained from the resin of burial urns and charcoal collected inside stone cairns excavated in 1930. These place the burials between 360 cal BC-510 AD (Ua-2547: 2165 \pm 60 BP, Ua-2545: 1975 \pm 70 BP, Ua-2546: 1960 \pm 70 BP, Su-3297: $1660 \pm 50$ BP; Edgren, 1992; Lavento 2003).

\section{TENTATIVE ${ }^{14} \mathrm{C}$ CHRONOLOGY}

\section{The temporal frequency of dates and sites}

Of the 94 radiocarbon dates from Stone Age and Early Metal Period sites in the study area, 81 were evaluated as useful for building an archaeological radiocarbon chronology (Table 3). In the Fig. 7 the distribution of dates is presented in two commonly used ways, as a relative probability of radiocarbon dates (summed with the CALPAL program), as well as grouped into a histogram in 500-year intervals by the calibrated median dates. Since there might be more than one date from the same context, causing bias, also the number of ${ }^{14} \mathrm{C}$ dated occu- pation episodes was counted (Kuzmin and Keates, 2005; Buchanan et al. 2008): the dates falling within the same 500 radiocarbon year interval from the same context were combined as single episodes using the R_Combine function of Oxcal program (Shennan and Edinborough, 2007), and plotted both as a relative probability and as a histogram by the median dates. The frequency of occupation episodes noticeably evens out the peaks shown by the frequency of dates. Also a histogram presenting the number of sites connected to each period is shown for comparison (Fig. 7).

As the study area still has a relatively meager number of radiometric dates, the whole distribution is subtle to changes with the addition of new dates. At present there is a relatively close match between the frequencies of sites, dates and dated occupation episodes. Whether this presents the current research situation or something else should be approached critically and scrutinized as new data accumulates.

\section{Factors affecting the temporal frequency of dates and sites}

Temporal frequency distributions of radiometric dates have been recently used to study various aspects of prehistory, e.g. population dynamics or neolithization (e.g. Kuzmin and Orlova, 2000; Lavento, 2004; Dolukhanov et al., 2002; Derevianko et al., 2004; Tallavaara et al., 2010; Timofeev and Zaitseva, 1991). However, the logic of using simply the rate of radiocarbon dates or the number of sites, for making interpretations of past population developments seems rather one-dimensional. The reasons behind each scientist's decision to date something vary widely, starting from obtaining the funds for radiometric dating to scientists' personal interests (e.g. Oinonen et al., 2010). Therefore the reasoning should always be backed up with other types of data and possible sources of error taken carefully into account (see Surovell et al., 2009).
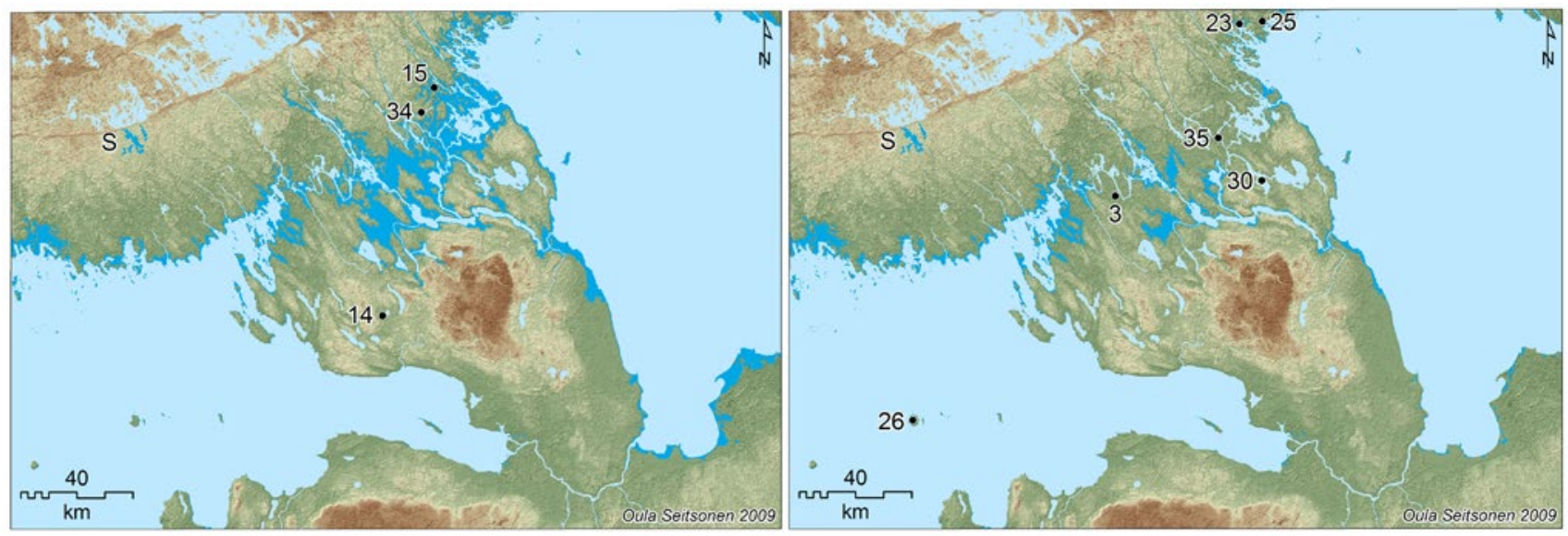

Fig. 6. Distribution of ${ }^{14} \mathrm{C}$ dated Early Metal Period sites; Left: Sites dating before the Lake Ladoga transgression maximum ca. 1350 cal BC, darker blue water levels are reconstructed to the transgression maximum period. Right: Sites dating after the formation of River Neva about 1350 cal BC, water levels reconstructed to the situation a few hundred years later (Map: O. Seitsonen). 

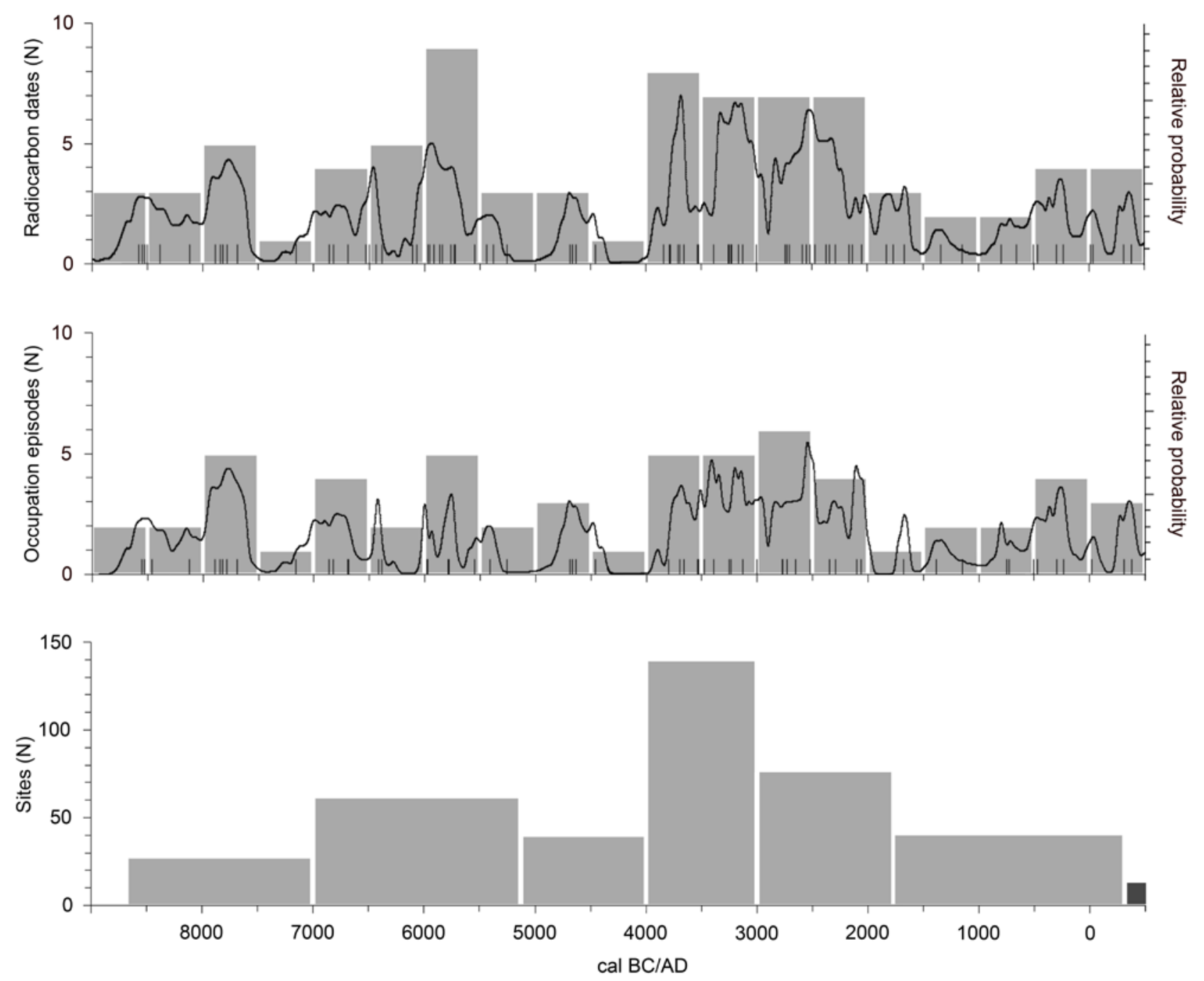

Fig. 7. Left: Frequencies of ${ }^{14} \mathrm{C}$-dates (top), and ${ }^{14} \mathrm{C}$-dated occupation episodes (middle) plotted with the CALPAL as a relative probability (solid line, scale on the right), and presented in a histogram in 500-year intervals (median dates; scale on the left); histogram in the bottom illustrates the number of archaeological sites for each period, start of the Middle Iron Age is shown with darker grey (based on the KarAS database).

As an obvious example, one could envisage that in our study area the excavation budgets have been saved when apparently recognizable context has been studied, and funds have been targeted for dating e.g. Mesolithic contexts with few typologically datable finds, or the poorly known Late Neolithic period. The former scenario is evident in the high number of Early Mesolithic dates, owing to the research projects targeted for locating the earliest pioneer sites (e.g. Jussila and Matiskainen, 2003; Takala, 2004).

The plain number of sites is neither a very good measure of population dynamics, since different kinds of locations have varying archaeological visibility through time. Therefore the questions related to the distribution and intensity of settlement should be inspected against diverse types of data, instead of the sheer number of sites or radiocarbon dates (see Gallivan, 2002; Surovell et al.,
2009). In the study area there are clear indications of heightened archaeological visibility of sites connected to some periods, especially to CW2: sites belonging to this period are typically more find-rich, have more house-pits visible to the surface, cover larger areas, and the ceramics preserve well and are easily recognizable (Fig. 8). Differences in the archaeological visibility suggest actual temporal changes in the settlement use and behavior, in the quality and quantity of material culture, and in the useduration of sites, connected e.g. to sedentariness. These trends have to be closely examined before drawing any conclusions of the site frequencies through time, and will be discussed by the authors more closely elsewhere.

Also the extensive hydrological changes caused by the post-glacial interplay of isostatic rebound of Earth's crust and water level fluctuations affect the visibility of sites during certain periods. Although the dated sites are 

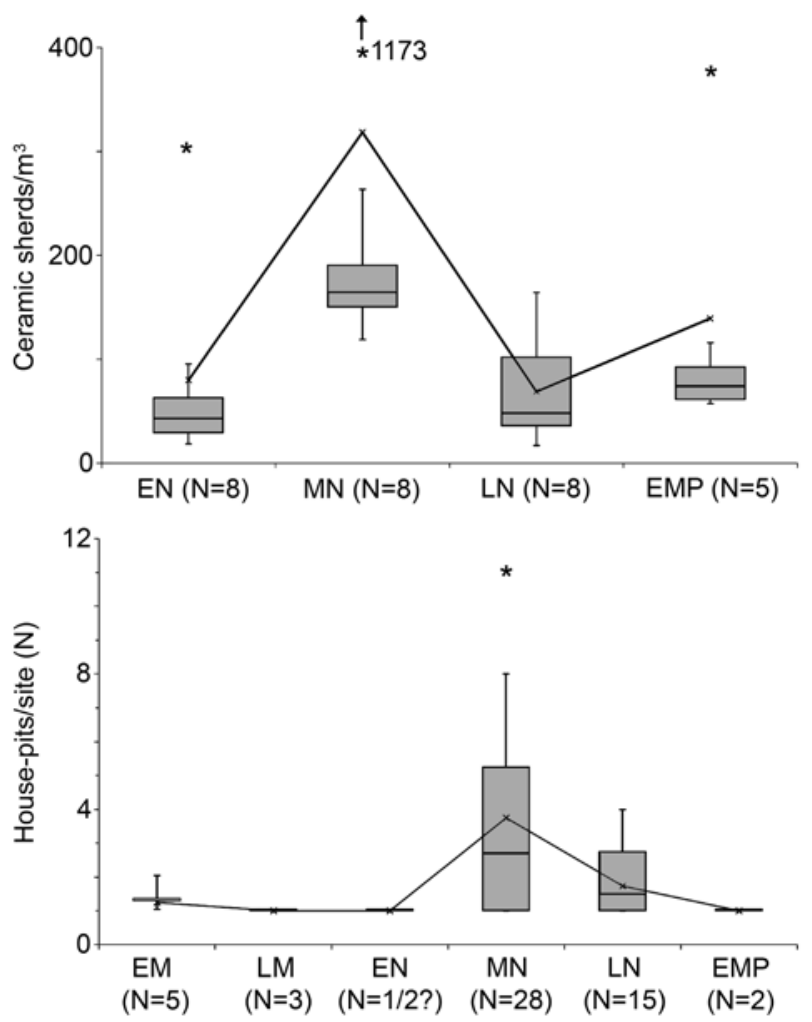

Fig. 8. Top: Number of ceramics at some recently excavated sites (sherds $/ \mathrm{m}^{3}$; outliers present vessels broken in-situ); Bottom: Number of house-pits at house-pit sites (based on the KarAS database; grey box presents the 1 st and 2 nd quartiles, whiskers the minimum and maximum, stars the outliers, and solid line the mean value).

generally in accordance with the tilted palaeo-shoreline reconstructions suggested for Lake Ladoga and Gulf of Finland (see Gerasimov and Subetto, 2009; Saarnisto, 2008), new phenomena have started to emerge. As an example, the hydrological history might partly explain the dearth of Early Neolithic dates; Early Neolithic is concurrent with some of the lowest Stone Age water levels within the Lake Ladoga catchment, pre-dating the transgression-causing outbreak of Lake Saimaa waters through the Salpausselkä watershed. All the unambiguous CW1 dates derive from contexts covered by transgressions, and locating more inundated sites is thus a relevant task in the future. Also the Early Metal Period sites predating the formation of River Neva around $1350 \mathrm{cal} \mathrm{BC}$ seem to have been submerged by the Lake Ladoga transgression maximum (see Fig. 6). Conversely, due to the interplay of waterlevel changes and land uplift, the abundant Middle Neolithic finds are situated on some of the highest Stone Age-Early Metal Period shorelines encountered in the intensively studied northern shore of Lake Ladoga - this picture might be balanced when more data is gathered from the less well studied southern and western parts.
Also in parts of Finland the temporal water level fluctuations and changes in archaeological visibility are probably one reason for the increase in the number of sites and ${ }^{14} \mathrm{C}$ dates during the Middle Neolithic (Siiriäinen, 1981; Tallavaara et al., 2010), as substantial transgressions took place also in the intensively studied and ${ }^{14} \mathrm{C}$ dated Lake Region of Eastern Finland (e.g. Saarnisto 1970). Further, thinking of the overall site distribution in Southern Finland and Karelian Isthmus, it should be kept in mind that the area south of Salpausselkä watershed was dotted in the past by currently dry lakes, shores of which offer excellent but so far little studied targets for archaeological surveys (e.g. Matiskainen and Ruohonen, 2004; Mökkönen and Seitsonen, 2007; Seitsonen, 2010). Also, the settlement patterns seem to become less shoreline connected from the Late Neolithic period onwards (e.g. Nordqvist and Seitsonen 2008; Mökkönen 2008) Thus it seems that modeling for various taphonomic bias (see Surovell et al., 2009) is needed to get a fuller picture of the site and date frequencies.

\section{Multi-period sites}

Stone Age and Early Metal Period of the Karelian Isthmus are largely characterized by multi-period sites, i.e. locations recurrently occupied through several millennia (e.g. Pälsi, 1920a; Mökkönen 2009; Seitsonen et al., 2009). This is mirrored in the radiometric dates: over one third of them come from three recently excavated multi-period sites.

At all three sites the dates and find material point to recurrent use from (at least) the Late Mesolithic to the Early Metal Period, if not even longer. The dates from Pyhäjärvi Kunnianniemi (11\% of all dates) and Muolaa Silino (10\% of all dates) cover evenly the time-span presented by archaeological material (plotted with the CALPAL program; Fig. 9). Conversely, the dates from Räisälä Juoksemajärvi Westend (12\% of all dates) lean towards the Late Neolithic and Early Metal Period, although also Mesolithic as well as Early and Middle Neolithic material is present. This example shows how the apparently large number of radiocarbon dates can be deceptive, and underlines that the dates must be cross-checked against other data.

Also several other multi-period sites have been radiocarbon dated, although none to the same extent as the above-mentioned sites (e.g. Kaukola Rupunkangas 1, Heinjoki Latukangas 1, Viipuri Ozernoe 3, to name a few). Based on the find materials, these and other sites show similar temporal continuity as the three sites discussed above, ranging from the Late Mesolithic to the Early Metal Period (e.g. Huurre, 2003; Pälsi, 1918; 1920a; Seitsonen, 2004; 2006).

\section{Spatial distribution of the dated sites}

The regional distribution of ${ }^{14} \mathrm{C}$ dates is naturally dictated by the concentration of research: over half of the 


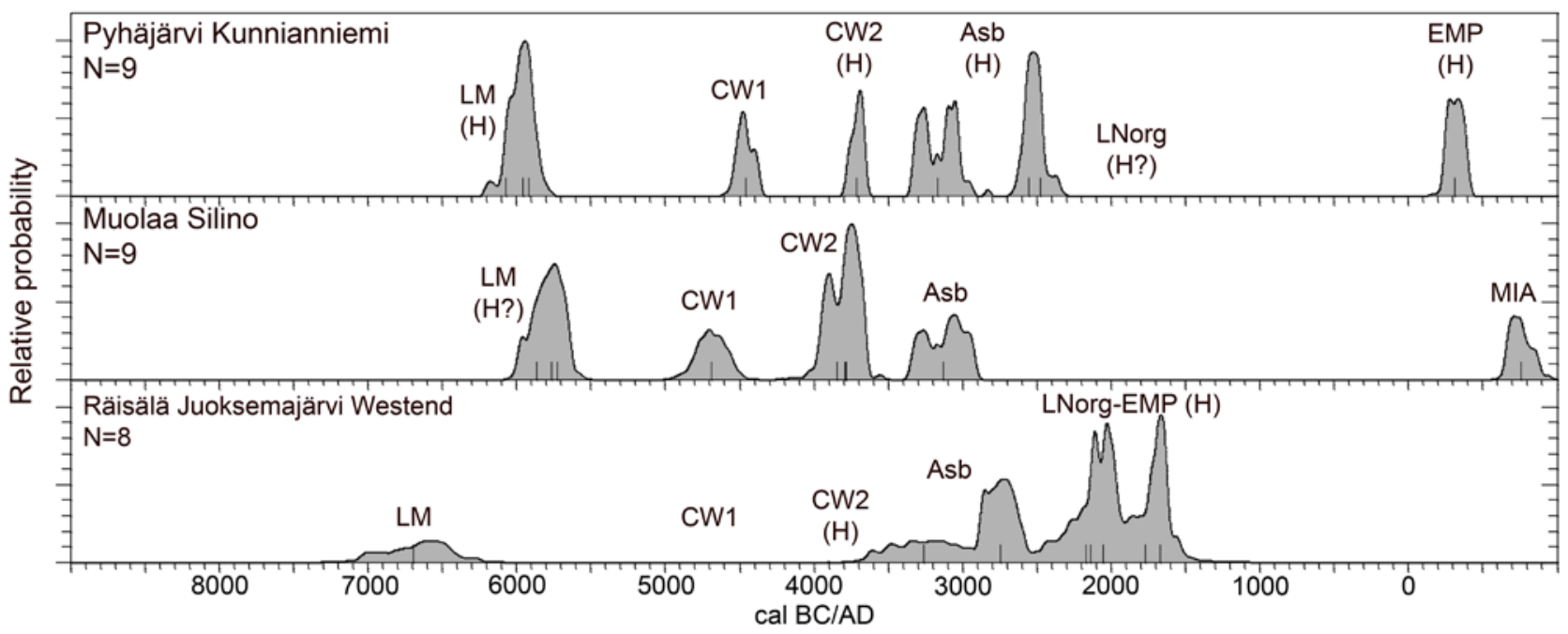

Fig. $9 .{ }^{14} \mathrm{C}$ dates and find contexts from the most comprehensively dated multi-period sites: Pyhäjärvi Kunnianniemi, Muolaa Silino, and Räisälä Juoksemajärvi Westend (plotted with the CALPAL program). Archaeological contexts as evidenced by the find material (from the whole sites, not only excavations): $L M=L a t e$ Mesolithic, CW1=Early Combed Ware, CW2=Typical Combed Ware, Asb=Kierikki/Pöljä Ware, LNorg=Late Neolithic organictempered ceramics, EMP=Early Metal Period; MIA=Middle Iron Age; $(H)=$ house-pit.

dates come from four municipalities, Räisälä $(19 \%)$, Pyhäjärvi (13\%), Muolaa (10\%) and Kaukola (10\%), which also account for half of all the archaeological fieldwork conducted in the Karelian Isthmus (KarAS database). This distinction is even more evident when the different parts of the study area are compared: the research-wise neglected southern part exhibits only a few solitary dates and sites (see Figs. 3, 5-6).

The temporal scale of dates is spatially hampered also in other respects. Only few parts of the study area exhibit radiocarbon dates from all the discussed periods, although find material from all these periods is encountered over the whole area. Even within the most studied municipalities the distribution of dates can be biased when mirrored against the excavated materials: as an example, in Kaukola the ${ }^{14} \mathrm{C}$ dates lean heavily towards the Mesolithic, despite the large, find-rich Neolithic multi-period dwelling sites known from the municipality since the early 1900s (Pälsi, 1920a).

\section{Other problems in constructing a ${ }^{14} \mathrm{C}$ chronology}

The difficulties in constructing a chronology are obviously greatest for periods with few dates and where the majority of dates are conventional. Conventional dates present certain difficulties, like the "old wood" effect (e.g. Schiffer, 1986; Carpelan, 2004) and correlation of the dated samples with archaeological finds. To avoid these problems the current trend is to move towards dating items of direct human manufacture or modification, such as charred crust on ceramics or burnt bone fragments, with the Accelerator Mass Spectrometry (AMS) method. Accordingly, over $60 \%$ of the dates presented in this paper are AMS dates, and nearly $50 \%$ of these derive from human modified materials.
Considering the dated materials, almost $50 \%$ of the samples are charcoal, while burnt bone and crust on ceramics cover ca. $40 \%$ of dated samples. Rest of the dates derive from anomalous materials, such as birch or pine bark, willow cord or resin "chewing gum" (Table 2). There are also differences in the dated materials between different periods: bone dates are more common in the Mesolithic contexts than in the Neolithic or Early Metal Period contexts, where charcoal dominates. The differences in the dated materials naturally have an effect in the accuracy: in some cases the "old wood" effect is a potential explanation for the discrepancies between dates and find materials.

\section{Tentative ${ }^{14} \mathrm{C}$ chronology in the Karelian Isthmus}

Although the number of radiometric dates from the Karelian Isthmus is still relatively small, we present a tentative ${ }^{14} \mathrm{C}$ chronology for the area (Fig. 10). However, as new radiometric dates accumulate, the proposed chronology needs constant re-evaluation and updating.

The role of radiometric dating has been already central for example in establishing the scope and age of the area's (Early) Mesolithic habitation. Also, based on the presented scheme no major decline is evident in the Early Metal Period habitation, contrary to what has been proposed earlier (e.g. Äyräpää, 1935; Lavento 2001; 2003). Currently Early Metal Period seems relatively well represented, albeit poorly studied; this discrepancy might derive e.g. from change towards more mobile settlement patterns, smaller site sizes, and changing material culture, as well as from fluctuating waterlevels. In addition, the divergences observed in the dating of some ceramic types as compared to the nearby areas might be significant. 


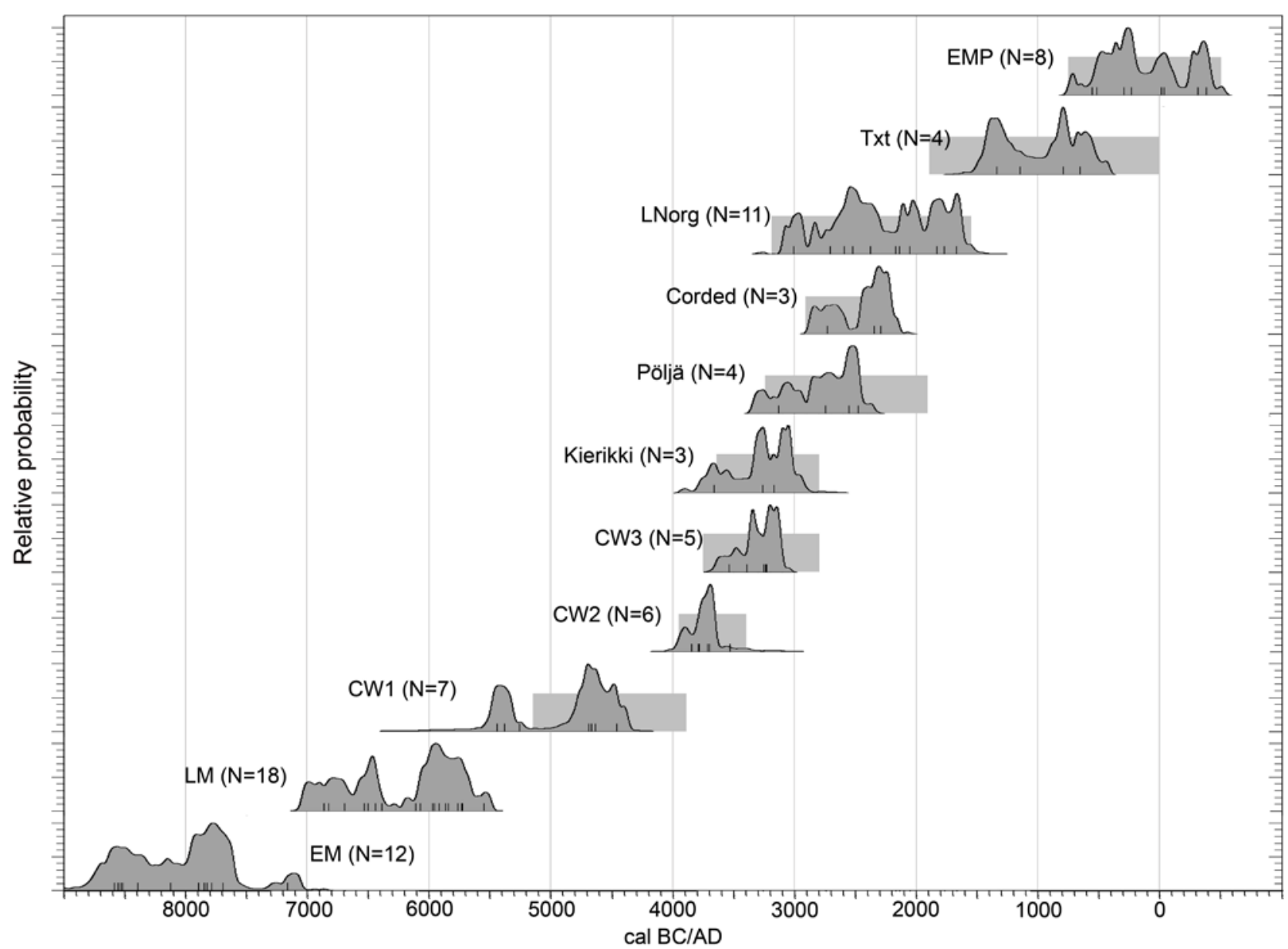

Fig. 10. Stone Age and Early Metal Period ${ }^{14} \mathrm{C}$ chronology in the study area (plotted with the CALPAL program), and the datings of ceramics in Finland (grey baulks; based on Carpelan 1999; Pesonen 2004; Tallavaara et al. 2010; Mökkönen 2011); EM=Early Mesolithic, LM=Late Mesolithic, CW1=Early Combed Ware (note: also the tentative early dates are shown), CW2=Typical Combed Ware, CW3=Late Combed Ware, Kierikki=Kierikki ceramics, Pöljä=Pöljä ceramics, Corded=Corded Ware, LNorg=Late Neolithic organic-tempered ceramics (cf. CW3/Pyheensilta/Kiukainen ceramics), Txt=Textile Ware, EMP=later Early Metal Period (note: grey baulk presents the dating of Luukonsaari Ware).

Even though these observations are currently based on a few dates, they offer guidelines for future research.

In the future an effort should be made to tie the cultural sequences in Finland, the Karelian Isthmus, the Republic of Karelia, and the areas south of Gulf of Finland more comprehensively together, fusing or at least connecting the currently separate typologies and chronologies. In order to build up local as well as inter-regional ceramic chronologies, especially ceramic sherds with charred crust should be dated. Also, considering the future prospects, the traditional use of ceramics as fossils directeurs in the Stone Age and Early Metal Period research could be a subject for wider and more methodological discussion. A more holistic approach, combining e.g. the various traits of material culture, the faunal and floral remains, other traces of livelihoods, and the landuse patterns, might provide somewhat differing views of the chronology and cultural developments.

\section{CONCLUSIONS}

The number of radiocarbon dates currently available from the Karelian Isthmus starts to be sufficient for forming a ${ }^{14} \mathrm{C}$ chronology covering the Stone Age and Early Metal Period. In this study the evaluation of radiocarbon dates into the Good, the Bad, and the Weird categories proved to be worthwhile and the used principles fit for use. These criteria could be used and developed for assessing dates in an analogous, systematic manner also in the nearby areas to facilitate comparisons. Further, as new dates amass from the study area, the evaluation will be carried out to enable adjustments of the chronology.

Dates show that the pioneer settlers arrived to the area soon after the deglaciation. After this the number of dates and sites grows constantly for the rest of the Mesolithic period. Early Neolithic dates are few, probably due to the taphonomic bias caused by the hydrological history, and are followed by an increase in both dates and sites in the 
Middle Neolithic. The observable rise in the number of sites and dates in the beginning of Middle Neolithic seems to be exaggerated by the differing archaeological visibility, e.g. by the increases in site size and find frequencies, apparently connected to actual differences in settlement behavior over time, and also by the typologically easily datable ceramic materials. The Late Neolithic period is also well represented, but towards the Early Metal Period the material evidence decreases. This is probably again biased by the hydrological fluctuations and affected by changes in the settlement patterns and material culture; however, the Early Metal Period remains visible in the light of ${ }^{14} \mathrm{C}$ dates.

The chronology formed by the available dates follows roughly the chronology used in Finland, both in the temporal distribution of dates and dating of ceramic types. However, for some ceramic types tentative divergences are discernible, and should be examined more closely in future. This is, besides defining the scope of Mesolithic and Early Metal Period habitations, among the most important observations considering the ${ }^{14} \mathrm{C}$ chronology of the Karelian Isthmus. Especially materials with little or no own age and directly related to the ceramics, such as charred crust, needs to be dated to refine the sequence.

The present ${ }^{14} \mathrm{C}$ database has also severe deficiencies. The so far limited number and skewed spatial coverage, caused by the research situation and taphonomic factors, introduces possible sources of error. Hence the suggested chronology is prone to changes with the addition of new dates. At the same time, this tendency towards alteration provides a key for further development and refinement of the chronology of Stone Age and Early Metal Period in the Karelian Isthmus, and also in the wider area.

\section{ACKNOWLEDGEMENTS}

The authors wish to thank the anonymous reviewers for their insightful and constructive comments, and Mrs. Sanna Seitsonen of the University of Helsinki for reading and commenting on an earlier draft of the paper. We also express our gratitude to all the friends and colleagues who have taken part in the fieldwork in the Karelian Isthmus over the last 10 years. The dates published for the first time in this paper were funded by Karjalaisen Kulttuurin Edistämissäätiö, Karjalan kulttuurirahasto, South Karelia Regional Fund of the Finnish Cultural Foundation, Vpl. Pyhäjärvi Foundation, and the 'Lake Pyhäjärvi - ozero Otradnoe' - project (director: O. Seitsonen).

\section{REFERENCES}

Äyräpää A, 1935. Etelä-Karjalan historian pääpiirteet (Main features of the South Karelian history). In: Äyräpää A, Aaltonen E and Meurman OI, eds., Neljännet museopäivät Viipurissa 1934. Suomen museoliiton julkaisuja, Helsinki, 5: 37-63 (in Finnish).

Bronk Ramsey C, 2001. Development of the radiocarbon program OxCal. Radiocarbon 43(2): 355-363.
Buchanan B, Collard M and Edinborough K, 2008. Paleoindian demography and the extraterrestrial impact hypothesis. PNAS 105(33): 11651-11654, DOI 10.1073/pnas.0803762105.

Carpelan C, 1999. Käännekohtia Suomen esihistoriassa aikavälillä $5100 \ldots 1000 \mathrm{eKr}$ (Turning points in the Finnish prehistory between $5100 \ldots 1000$ BC). In: Fogelberg P, ed, Pohjan poluilla: Suomalaisten juuret nykytutkimuksen mukaan. Bidrag till kännedom av Finlands natur och folk, Helsinki, 153: 249-280 (in Finnish).

Carpelan C, 2004. Environment, Archaeology and Radiocarbon dates. Notes from the Inari Region, Northern Finnish Lapland. In: Lavento M, ed., Early in the North, Volume 5. Iskos, Helsinki, 13: 17-45.

Carpelan C, 2008. On the history and recent studies of the 'Antrea Net Find'. In: Lavento M, ed., Karelian Isthmus. Stone Age studies in 1998-2003. Iskos, Helsinki, 16: 88-127.

Carpelan C, Uino P and Gerasimov DV, 2008. Archaeology in the former municipality of Johannes. In: Lavento M, ed., Karelian Isthmus. Stone Age studies in 1998-2003. Iskos, Helsinki, 16: 185214.

Derevianko AP, Kuzmin YP, Burr GS, Jull AJT and Kim JC, 2004. AMS $14 \mathrm{C}$ age of the earliest pottery from the Russian Far East: 1996-2002 results. Nuclear Instruments and Methods in Physics Research B 223-224: 735-739, DOI 10.1016/j.nimb.2004.04.136.

Dolukhanov PM, Shukurov AM, Tarasov PE and Zaitseva GI, 2002. Colonization of Northern Eurasia by modern humans: Radiocarbon chronology and environment. Journal of Archaeological Science 29(6): 593-606, DOI 10.1006/jasc.2001.0753.

Dolukhanov P, Shukurov A, Gronenborn D, Sokoloff D, Timofeev V and Zaitseva G, 2005. The chronology of Neolithic dispersal in Central and Eastern Europe. Journal of Archaeological Science 32(10): 1441-1458, DOI 10.1016/j.jas.2005.03.021.

Edgren T, 1966. Jäkärlä-gruppen. En västfinsk kulturgrupp under yngre stenålder (Jäkärlä-group. West Finnish cultural group in the younger Stone Age). Suomen Muinaismuistoyhdistyksen Aikakauskirja, Helsinki, 64: 159pp (in Swedish).

Edgren T, 1992. Den förhistoriska tiden (Prehistoric period). In: Norrback M, ed., Finlands historia 1. Esbo, Schildts: 9-270 (in Swedish).

Gallivan MD, 2002. Measuring Sedentariness and Settlement Population: Accumulations Research in the Middle Atlantic Region. American Antiquity 67: 535-557.

Gerasimov DV and Kul'kova MA, 2003. Hronologičeskaja atribucija arheologičeskih kompleksov mnogoslojnyh pamjatnikov Silino i Bol'šoe Zavetnoe 4 na Karel'skom perešejke po geohimičeskim dannym (Chronological attributes of the archaeological complexes at multilayered sites Silino and Bol'šoe Zavetnoe 4 in the Karelian Isthmus based on geochemical data). In: Timofeev VI and Sinicyna GV, eds., Neolit - èneolit Juga i neolit Severa Vostočnoj Evropy. Sankt-Peterburg, Rossijskaja akademija nauk: 181-192 (in Russian).

Gerasimov DV and Subetto DA, 2009. Istorija Ladožskogo ozera v svete arheologičeskih dannyh (History of Lake Ladoga in the light of archaeological data). Izvestija Rossijskogo gosudarstevennogo pedagogičeskogo universiteta imeni A.I. Gercena 106: 37-49 (in Russian).

Gerasimov DV, Lisicyn SN and Timofeev VI, 2003. Materialy k arheologičeskoj karte Karel'skogo perešejka (Leningradskaja oblast'). Pamjatniki kamennogo veka i perioda rannego metalla (Material for the archaeological map of Karelian Isthmus (Leningrad oblast). Stone Age and Early Metal Period sites). Sankt-Peterburg, Rossijskaja akademija nauk: 68pp (in Russian).

Gerasimov DV, Nordkvist K, Sejtsonen O and Subetto DA, 2007. Kompleksnoe izučenie pamjatnikov kamennogo veka v mikroregione Otradnoe na Karel'skom perešjke. Predvaritelnye itogi i perspektivy issledovanij (Multidisciplinary study of Stone Age sites in the Otradnoe micro-region in the Karelian Isthmus. Preliminary results and research perspectives). Materialy polevyh issledovanij MAE RAN 7: 79-103 (in Russian).

Gerasimov DV, Sejtsonen O and Nordkvist K, 2008. "Beregovaja hronologija" i istorija Ladogi v svete rezul'tatov raskopok arheologičeskoe kompleksa Komsomol'skoe 3 v 2007 g ("Shoreline chronology" and history of Ladoga in the light of excavations of 
the archaeological complex Komsomol'skoe 3 in 2007). Radlovskij sbornik. Naučnye issledovanija i muzejnye proekty MAÈ RAN $v 2007$ g. Sankt-Peterburg, Rossijskaja akademija nauk: 188-193 (in Russian).

German KE, 2004. Problemy hronologii načal'nogo ètapa rannego neolita Severo-Vostočnoj Fennoskandii (Chronological problems of the initial stage of Early Neolithic of north-eastern Fennoscandia). In: Timofeev VI and Zaitseva GI, eds., Problemy hronologii i ètnokul'turnyh vzaimodejstvij v neolite Evrazii. SanktPeterburg, Rossijskaja akademija nauk: 56-59 (in Russian).

Gkiasta M, Russell T, Shennan S and Steele J, 2003. Neolithic transition in Europe: the radiocarbon record revisited. Antiquity 77(295): 4562

Gurina NN, 1961. Drevnjaja istorija Severo-Zapada Evropejskoj časti SSSR (Ancient history of the north-western part of USSR). Materialy $i$ issledovanija po arheologii SSSR 87. Moskva, Akademija Nauk SSSR: 584pp (in Russian).

Graf KE, 2009. "The Good, the Bad, and the Ugly": evaluating the radiocarbon chronology of the middle and late Upper Paleolithic in the Enisei River valley, south-central Siberia. Journal of Archaeological Science 36(3): 694-707, DOI 10.1016/j.jas.2008.10.014.

Hakulinen M, 2003. Luumäen Selänalajärvet (Selänalajärvet lakes at Luumäki). Lappeenranta, Etelä-Karjalan maakuntayhdistys. EteläKarjalan vuosikirja 2003: 1-9 (in Finnish).

Halinen P and Mökkönen T, 2009. Between Lake and Sea - Stone Age Settlement by Ancient Ladoga on the Karelian Isthmus. Fennoscandia archaeologica XXVI: 107-132.

Halinen P, Seitsonen O, Seitsonen S and Nordqvist K, 2008. Excavations at the Juoksemajärvi Westend Stone Age dwelling site in 2002. In: Lavento M, ed., Karelian Isthmus. Stone Age studies in 1998-2003. Iskos, Helsinki, 16: 235-265.

Huurre M, 2003. Viipurin läänin kivikausi (Stone Age of the Vyborg county). In: Saarnisto M, ed, Karjalan synty. Viipurin läänin historia 1. Sine loco, Karjalaisen Kulttuurin Edistämissäätiö, Karjalan Kirjapaino Oy: 151-244 (in Finnish).

Jungner H, 1979. Radiocarbon dates I. Helsinki, Radiocarbon Dating Laboratory. University of Helsinki: 131pp.

Jussila T and Matiskainen H, 2003. Mesolithic Settlement During the Preboreal period in Finland. In: Larsson L, Lindegren H, Knutson $\mathrm{K}$, Loefgren D and Åkerlund A, eds., Mesolithic on the move. Oxford, Oxbow books: 664-670.

Jussila T, Kriiska A and Rostedt T, 2007. The Mesolithic Settlement in NE Savo, Finland and the Earliest Settlement in the Eastern Baltic Area. Acta Archaeologica: 78(2): 143-162.

Krajnov DA, 1987. Volosovskaja kul'tura (Volosovo culture). In: Bader ON, Krajnov DA and Kosarev MF, eds., Époha bronzy lesnoj polosy SSSR. Moskva, Nauka. Arheologija SSSR: 10-28 (in Russian).

Kriiska A and Tvauri A, 2007. Viron esihistoria (Prehistory of Estonia). Helsinki, Suomalaisen Kirjallisuuden Seura: 252pp (in Finnish).

Kuzmin YV and Keates SG, 2005. Dates Are Not Just Data: Paleolithic Settlement Patterns in Siberia Derived from Radiocarbon Records. American Antiquity 70(4): 773-789.

Kuzmin YV and Orlova LA, 2000. The Neolithization of Siberia and the Russian Far East. Radiocarbon evidence. Antiquity 74: 356364.

Kuzmin YV and Tankerslay KB, 1996. The Colonization of Eastern Siberia: an Evaluation of the Paleolithic Age Radiocarbon Dates. Journal of Archaeological Science 23: 577-585, DOI 10.1006/jasc.1996.0054.

Lang V, 2006. Settlement and landscape archaeology in Estonia. Archaeological Research in Estonia 1865-2005. In: Lang V and Laneman M, eds., Estonian Archaeology 1. Tartu, Tartu University Press: 293-300.

Lang V and Kriiska A, 2001. Eesti esiaja perioodiseering ja kronoloogia (Periodisation and chronology of the Estonian prehistory). Estonian Journal of Archaeology 5: 83-109 (in Estonian).

Lavento M, 2001. Textile Ceramics in Finland and on the Karelian Isthmus - Nine variations and fugue on a theme of $C . F$. Meinander. Suomen Muinaismuistoyhdistyksen Aikakauskirja 109. Helsinki, The Finnish Antiquarian Society: 410pp.
Lavento M, 2003. Viipurin läänin pronssikausi ja varhaismetallikausi (Bronze Age and Early Metal Period of the Vyborg county). In: Saarnisto M, ed., Karjalan synty. Viipurin läänin historia 1 . Sine loco, Karjalaisen Kulttuurin Edistämissäätiö, Karjalan Kirjapaino Oy: 245-290 (in Finnish).

Lavento M, 2004. Chronology without types and cultures? Interpreting the prehistory of Kainuu on the basis of radiocarbon dates. FennoUgri et Slavi 2002. Dating and Chronology. Museoviraston arkeologian osaston julkaisuja, Helsinki, 10: 61-74.

Lavento M, ed., 2008. Karelian Isthmus. Stone Age studies in 19982003. Iskos, Helsinki, 16: 328pp.

Lisitsyn SN, 2003. Stojanka Tokarevo 1 na Severo-Zapade Karel'skogo perešejka (Tokarevo 1 site in the North-West Karelian Isthmus). In: Timofeev VI and Sinicyna GV, eds., Neolit - èneolit Juga i neolit Severa Vostočnoj Evropy. Sankt-Peterburg, Rossijskaja akademija nauk: 152-162 (in Russian).

Lisitsyn SN and Gerasimov DV, 2008. Okružajuŝaja sreda i čelovek v rannem golotsene Jugo- Vostočnoj Fennoskandii (Palaeoenvironment and people in the early Holocene southwest Fennoscandia). In: Put' na sever. Okružajuŝaja sreda i samye rannie obitateli Arktiki i Subarktiki. Moskva, Institut geografii RAN: 134-151 (in Russian).

Luoto J and Laakso V, 2001. Uusinta uutta Etelä-Karjalan esihistoriasta (Novelties in the South Karelian prehistory). Museoviesti 1/2001: 7-8 (in Finnish).

Matiskainen H, 1989. Studies on the chronology, material culture and subsistence economy of the Finnish Mesolithic, 10 000-6 000 b.p. Iskos, Helsinki, 8: 97pp.

Matiskainen H and Ruohonen J, 2004. Esihistorian pauloissa (In the snares of prehistory). Sine loco, Riihimäen kaupunginmuseo (in Finnish).

Meinander CF, 1954. Die Bronzezeit in Finnland (Bronze Age in Finland). Suomen Muinaismuistoyhdistyksen Aikakauskirja 54. Helsinki, The Finnish Antiquarian Society: 242pp (in German).

Michczyński A, 2007. Is it possible to find a good point estimate of a calibrated radiocarbon date? Radiocarbon 49(2): 393-401.

Miettinen A, Sarmaja-Korjonen K, Sonninen E, Jungner H, Lempiäinen T, Ylikoski K, Mäkiaho J-P and Carpelan C, 2008. The Palaeoenvironment of the 'Antrea Net Find'. In: Lavento M, ed., Karelian Isthmus. Stone Age studies in 1998-2003. Iskos, Helsinki, 16: 7187.

Mökkönen T, 2008. A review of Neolithic multi-room housepits seen from the Meskäärtty site in Virolahti parish, extreme SouthEastern Finland. Estonian Journal of Archaeology 12: 114-151, DOI 10.3176/arch.2008.2.02.

Mökkönen T, 2009. Neolithic House-pits in the Vuoksi River - Chronological Changes in Size and Location. Fennoscandia archaeologica XXVI: 133-161.

Mökkönen T, 2010. Kivikautinen maanviljely Suomessa (Stone Age agriculture in Finland). Suomen Museo 2009: 5-38 (in Finnish).

Mökkönen T, 2011. Studies on Stone Age housepits in Fennoscandia (4000-2000 CAL BC). Changes in ground plan, site location, and degree of sedentism. Helsinki, Unigrafia: 86pp.

Mökkönen T, Nordqvist K and Bel'skij S, 2007. The Rupunkangas 1A Site in the Archipelago of the Ancient Lake Ladoga: a House-pit with Several Rebuilding Phases. Fennoscandia archaeologica XXIV: $3-28$

Mökkönen T and Seitsonen O, 2007. Virolahden pyyntikulttuurien inventointi vuonna 2005 (Survey of the forager cultures at Virolahti in 2005). Muinaistutkija 2/2007: 20-39 (in Finnish).

Nordqvist K and Seitsonen O, 2008. Archaeological research in Koivisto and Kuolemajärvi parishes in 2003: results and observations. In: Lavento M, ed., Karelian Isthmus. Stone Age studies in 19982003. Iskos, Helsinki, 16: 215-234.

Nordqvist K, Seitsonen O and Uino P, 2008. Appendix 1. Stone Age and Early Metal Period sites in the studied municipalities. In: Lavento M, ed., Karelian Isthmus. Stone Age studies in 19982003. Iskos, Helsinki, 16: 291-328.

Nordqvist K, Seitsonen O and Lavento M, 2009. Waterways and the Stone Age and Early Metal Period studies on the Karelian Isthmus - The Pre-World War II studies and the research carried out by the 
University of Helsinki in 1998-2006. Quaternary International 203(1-2): 25-32, DOI 10.1016/j.quaint.2008.04.020.

Oinonen M, Pesonen P and Tallavaara M, 2010. Archaeological Radiocarbon Dates for Studying the Population History in Eastern Fennoscandia. Radiocarbon 52(2): 393-407.

Pälsi S, 1918. Kaivaus Pitkäjärven kivikautisella asuinpaikalla Räisälässä v. 1915 (Excavation at the Stone Age site of Pitkäjärvi in Räisälä in 1915). Suomen Museo XXV: 25-34 (in Finnish).

Pälsi S, 1920a. Riukjärven ja Piiskunsalmen kivikautiset asuinpaikat Kaukolassa (Stone Age sites at Riukjärvi and Piiskunsalmi in Kaukola). Suomen Muinaismuistoyhdistyksen Aikakauskirja 28(1). Helsinki, The Finnish Antiquarian Society: 180pp (in Finnish).

Pälsi S, 1920b. Ein steinzeitlicher Moorfund bei Korpilahti im Kirchspiel Antrea, Län Viborg (Stone Age bog find at Korpilahti in Antrea parish, Vyborg county). Suomen Muinaismuistoyhdistyksen Aikakauskirja 28(2). Helsinki, The Finnish Antiquarian Society: 20pp (in German).

Pesonen P, 1996. Early Asbestos Ware. In: Kirkinen T, ed., Pithouses and potmakers in Eastern Finland. Reports of the Ancient Lake Saimaa Project. Helsinki Papers in Archaeology, Helsinki, 9: 939.

Pesonen P, 2004. Neolithic pots and ceramics chronology - AMSdatings of Middle and Late Neolithic ceramics in Finland. In: Uino P, ed., Fenno-Ugri et Slavi. Dating and Chronology. Museoviraston arkeologian osaston julkaisuja, Helsinki, 10: 87-97.

Pettitt PB, Davies W, Gamble CS and Richards MB, 2003. Palaeolithic radiocarbon chronology: quantifying our confidence beyond two half-lives. Journal of Archaeological Science 30(12): 1685-1693, DOI 10.1016/S0305-4403(03)00070-0.

Reimer PJ, Baillie MGL, Bard E, Bayliss A, Beck JW, Blackwell PG, Bronk Ramsey C, Buck CE, Burr GS, Edwards RL, Friedrich M, Grootes PM, Guilderson TP, Hajdas I, Heaton TJ, Hogg AG, Hughen KA, Kaiser KF, Kromer B, McCormac FG, Manning SW, Reimer R.W, Richards DA, Southon JR, Talamo S, Turney CSM, van der Plicht J and Weyhenmeyer CE, 2009. IntCal09 and Marine 09 radiocarbon age calibration curves, $0-50,000$ years cal BP. $R a-$ diocarbon 51(4): 1111-1150.

Rudenko SI, 1970. Opyt primenenija metodov estestvennyh nauk k issledovaniju neolitičeskih pamjatnikov (Experiment to apply natural scientific methods into study of Neolithic sites). Doklady otdelenij i komissij Geografičeskogo obščestva SSSR. Vyp 15: 3859 (in Russian).

Saarnisto M, 1970. The Late Weichselian and Flandrian History of the Saimaa Lake Complex. Commentationes Physico-Mathematicae 37. Helsinki, Societas Scientiarum Fennica: 107pp.

Saarnisto M, ed., 2003. Karjalan synty. Viipurin läänin historia 1 . Sine loco, Karjalaisen Kulttuurin Edistämissäätiö, Karjalan Kirjapaino Oy: 560pp (in Finnish).

Saarnisto M, 2008. Emergence history of the Karelian Isthmus. In: Lavento M, ed., Karelian Isthmus. Stone Age studies in 19982003. Iskos, Helsinki, 16: 128-139.

Sapelko TV, Ludikova AV, Kul'kova MA, Kuznecov DD, Gerasimov DV and Subetto DA, 2008. Rekonstrukcija sredy obitanija čeloveka na territorii Karel'skogo perešejka (po materialam issledovanija mnogoslojnogo poselenija Ozernoe 3) (Reconstruction of the environmental habitat of the people in the territory of Karelian Isthmus [based on the investigations at multilayered site Ozernoe 3]). Hronologija, periodizacija i krosskul'turnye svjazi v kamennom veke. Zamjatninskij sbornik 1: 148-163 (in Russian).

Schiffer MB, 1986. Radiocarbon dating and the "old wood" problem: The case of the Hohokam chronology. Journal of Archaeological Science 13(1): 13-30, DOI 10.1016/0305-4403(86)90024-5.

Seitsonen O, 2004. Viipurin Häyrynmäen kivikautinen asuinpaikka (Stone Age dwelling site of Viipuri Häyrynmäki). Muinaistutkija 1/2004: 19-30 (in Finnish).

Seitsonen O, 2006. Räisälä Pitkäjärvi revisited - reinterpretations of the dwelling remains. Arkeologipäivät 2005: 138-145.

Seitsonen O, 2010. Kytäjän muinaislöydöt (Ancient finds at Kytäjä). Mennyttä aikaa muistellen, Kytäjä ennen ja nyt: 163-177 (in Finnish).
Seitsonen O and Gerasimov DV, 2008. Archaeological research in the Kurkijoki area in 2001 and 2003: A preliminary study of the Stone Age settlement patterns in southern Ladoga Karelia. In: Lavento M, ed., Karelian Isthmus. Stone Age studies in 1998-2003. Iskos, Helsinki, 16: 164-184.

Seitsonen O and Nordqvist K, 2009. Chronology of the multi-layered Stone Age and Early Metal Period site Kunnianniemi (Komsomol'skoe 3), Karelian Isthmus, Russia. In: Vasil'ev SA, ed., Vzaimodejstvie $i$ hronologija kul'tur mezolita $i$ neolita Vostočnoj Evropy. Materialy meždunarodnoj naučnoj konferencii, posvjacennoj 100-letiju N.N.Gurinoj. Sankt-Peterburg, Rossijskaja akademija nauk: 36-37 (in Russian).

Seitsonen O, Nordqvist K and Gerasimov DV, 2009. Recent archaeological research in Lake Pyhäjärvi micro-region, Karelian Isthmus, Russia: The multi-period site of Pyhäjärvi Kunnianniemi and new Early Combed Ware period finds. Fennoscandia archaeological XVI: 163-171.

Shennan S and Edinborough K, 2007. Prehistoric population history: from the Late Glacial to the Late Neolithic on Central and Northern Europe. Journal of Archaeological Science 34(8): 1339-1345, DOI 10.1016/j.jas.2006.10.031.

Siiriäinen A, 1974. Studies Relating to Shore Displacement and Stone Age Chronology in Finland. Finskt Museum 80: 5-22.

Siiriäinen A, 1981. On the cultural ecology of the Finnish Stone Age. Suomen Museo 87: 5-40.

Sorokin PE, Gusencova TM and Ekimova AA, 2009. Neolit i èneolit poselenija Ohta I v Sankt-Peterburge (Neolithic-Eneolithic site Ohta I in St. Petersburg). In: Vasil'ev SA, ed., Vzaimodejstvie i hronologija kul'tur mezolita i neolita Vostočnoj Evropy. Materialy meždunarodnoj naučnoj konferencii, posvjacennoj 100-letiju N.N.Gurinoj. Sankt-Peterburg, Rossijskaja akademija nauk: 101103 (in Russian).

Spriggs M, 1989. The dating of the island Southeast Asian Neolithic: an attempt at chronometric hygiene and linguistic correlation. Antiquity 63: 587-613.

Surovell TA and Brantingham PJ, 2007. A note on the use of temporal frequency distributions in studies of prehistoric demography. Journal of Archaeological Science 34(11): 1868-1877, DOI 10.1016/j.jas.2007.01.003.

Surovell TA, Byrd Finley J, Smith GM, Brantingham PJ and Kelly R, 2009. Correcting temporal frequency distributions for taphonomic bias. Journal of Archaeological Science 36(8): 1715-1724, DOI 10.1016/j.jas.2009.03.029.

Takala H, 2004. The Ristola site in Lahti and the earliest postglacial settlement of South Finland. Lahti, Lahti City Museum: 205pp.

Takala H and Sirviö T, 2003. Telkkälä, Muolaa - a multi-period dwelling site on the Karelian Isthmus. Fennoscandia archaeologica XX: $55-77$.

Tallavaara M, Pesonen P and Oinonen M, 2010. Prehistoric population history in eastern Fennoscandia. Journal of Archaeological Science 37(2): 251-260, DOI 10.1016/j.jas.2009.09.035.

Timofeev VI and Zaitseva GI, 1991. Rezultaty radiouglerodnogo datirovanija arheologičeskih pamjatnikov èpoha neolita $\mathrm{i}$ rannego metalla Leningradskoj i Kaliningradskoj oblastej (Results of radiocarbon dating the Neolithic and Early Metal Period archaeological sites of the Leningrad and Kaliningrad oblasts). Geohronologičeskie $i$ izotopno-himičeskie issledovanija $v$ četvertičnoj geologii $i$ arheologii. Vil'njus, Nauka: 123-130 (in Russian).

Timofeev VI and Gerasimov DV, 2003. Stojanki kamennogo veka èpohi rannego metalla na Karel'skom perešejke (Stone Age-Early Metal Period sites in the Karelian Isthmus). Arheologičeskie otkrytija 2002 goda. Moskva, Rossijskaja akademija nauk: 63-64 (in Russian).

Timofeev VI, Gerasimov DV, Lisitsyn SN, Halinen P and Lavento M, 2003. Issledovanija stojanok kamennogo veka na oz. Bol'shoe Zavetnoe (Research at a Stone Age site on the Lake Bol'shoe Zavetnoe). Arheologičeskie otkrytija 2002 goda. Moskva, Rossijskaja akademija nauk: 64-66 (in Russian).

Timofeev VI, Zaitseva GI, Lavento M, Dolukhanov P and Halinen P, 2004a. The radiocarbon datings of the Stone Age - Early Metal Period on the Karelian Isthmus. Geochronometria 23: 93-99. 
Timofeev VI, Zaitseva GI, Doluhanov PM and Šukurov AM, 2004b. Radiouglerodnaja hronologija neolita severnoj Evrazii (Radiocarbon chronology of the Neolithic of Northern Eurasia). SanktPeterburg, Teza: $157 \mathrm{pp}$ (in Russian).

Uino P, 1997. Ancient Karelia. Archaeological Studies - MuinaisKarjala. Arkeologisia tutkimuksia. Suomen Muinaismuistoyhdistyksen Aikakauskirja 104. Helsinki, The Finnish Antiquarian Society: 426pp.

Uino P, 2003. Karjalan arkeologiaa 150 vuotta (150 years of archaeology in Karelia). In: Saarnisto M, ed., Karjalan synty. Viipurin läänin historia 1. Sine loco, Karjalaisen Kulttuurin Edistämissäätiö, Karjalan Kirjapaino Oy: 117-150 (in Finnish).

Vereščagina IV, 2003. Poselenie Hepo-jarvi v južnoj časti Karel'skogo perešejka (Hepojarvi site in the southern part of Karelian Isthmus). In: Timofeev VI and Sinicyna GV, eds., Neolit - èneolit Juga i neolit Severa Vostočnoj Evropy. Rossijskaja akademija nauk, SanktPeterburg: 140-151 (in Russian).
Vikkula A, 1984. Pyheensilta ceramics - Facts and Theories. In: Edgren T, ed., Fenno-ugri et slavi 1983. Iskos, Helsinki, 4: 51-59.

Waterbolk HT, 1971. Working with radiocarbon dates. Proceedings of the prehistoric society 37: 15-33.

Ylikoski K, 2004. Antrean kivikautisen verkkolöydön iänmääritys (Determining the age of Antrea Stone Age net find). Unpublished M.A. thesis, Department of Geology and Palaeonthology, University of Helsinki (in Finnish).

Zaitseva GI and Dergachev VA, 2009. Radiocarbon chronology of the Neolithic sites from the Boreal zone of European Russia and environmental changes based on the last proxy data. Quaternary International 203(1-2): 19-24, DOI 10.1016/j.quaint.2008.04.012.

Žul'nikov AM, 2005. Poselenija èpohi rannego metalla JugoZapadnogo Pribelomor'ja (Early Metal Period sites in the southwestern White Sea area). Rossijskaja akademija nauk: 305pp, (in Russian). 